Andrews University

Digital Commons @ Andrews University

Professional Dissertations DMin

Graduate Research

1999

\title{
A Strategy for Ministry to the homeless in North London
}

Carl Thorpe

Andrews University

Follow this and additional works at: https://digitalcommons.andrews.edu/dmin

Part of the Practical Theology Commons

\section{Recommended Citation}

Thorpe, Carl, "A Strategy for Ministry to the homeless in North London" (1999). Professional Dissertations DMin. 613.

https://dx.doi.org/10.32597/dmin/613

https://digitalcommons.andrews.edu/dmin/613

This Project Report is brought to you for free and open access by the Graduate Research at Digital Commons @ Andrews University. It has been accepted for inclusion in Professional Dissertations DMin by an authorized administrator of Digital Commons @ Andrews University. For more information, please contact repository@andrews.edu. 


\section{ABSTRACT}

STRATEGY FOR MINISTRY TO THE

HOMELESS IN NORTH LONDON

by

Carl Thorpe

Adviser: R. Clifford Jones 


\section{ABSTRACT OF GRADUATE STUDENT RESEARCH}

\section{Dissertation}

Andrews University

Seventh-day Adventist Theological Seminary

Title: A STRATEGY FOR MINISTRY TO THE HOMELESS IN NORTH
LONDON Name of researcher: Carl Thorpe Name and degree of faculty adviser: R. Clifford Jones, D.Min.

Date completed: June 1999

Problem

Despite the benefits that the English Social Security provides, many individuals fall out of the safety net into abject poverty. Every night hundreds of individuals sleep rough. Exposed to the elements, these people are in need of food and a permanent place. The Seventh-day Adventist Church in North London is not providing an adequate ministry to meet the physical and spiritual needs of these people. This dissertation sets out to develop a strategy for ministry to the physical and spiritual needs of those who "sleep rough" in North London. 
Method

This study looks at various aspects relating to homelessness, looks at causes of homelessness, explores conditions faced by a specific class of homeless in North London (those who sleep on the street), and suggests a ministry to those who sleep on the street. It looks at a biblical rationale for ministry to the poor. The biblical evidence which was examined suggests that: (1) God is concerned about those who are oppressed; (2) God made provision for the poor through the Law of Release; (3) humankind will be judged based on how they relate to those who are in need; (4) Jesus' ministry demonstrates that the Jubilee was time for liberation. The study also looks at Ellen White's teaching on the poor. A strategy was constructed to address specific needs of those who sleep on the street. Among these needs are the need for food, the need for warm clothing, and the need for an address.

\section{Conclusion}

People who sleep on the street of North London have many problems. For example, the lack of a permanent address, the need for food and medical care. There is an urgent need to address conditions faced by those who sleep on the street. While this study should not be considered to be conclusive, it is hoped that the strategy will actively demonstrate Christ's exemplary ministry to those who are in need. 


\author{
Andrews University \\ Seventh-day Adventist Theological Seminary
}

\begin{abstract}
A STRATEGY FOR MINISTRY TO THE HOMELESS IN NORTH LONDON
\end{abstract}

\author{
A Dissertation \\ Presented in Partial Fulfillment \\ of the Requirements for the Degree \\ Doctor of Ministry
}

by

Carl Thorpe

June 1999 


\section{A STRATEGY FOR MINISTRY TO THE HOMELESS IN NORTH LONDON}

A dissertation

presented in partial fulfillment of the requirements for the degree Doctor of Ministry

by

Carl Thorpe
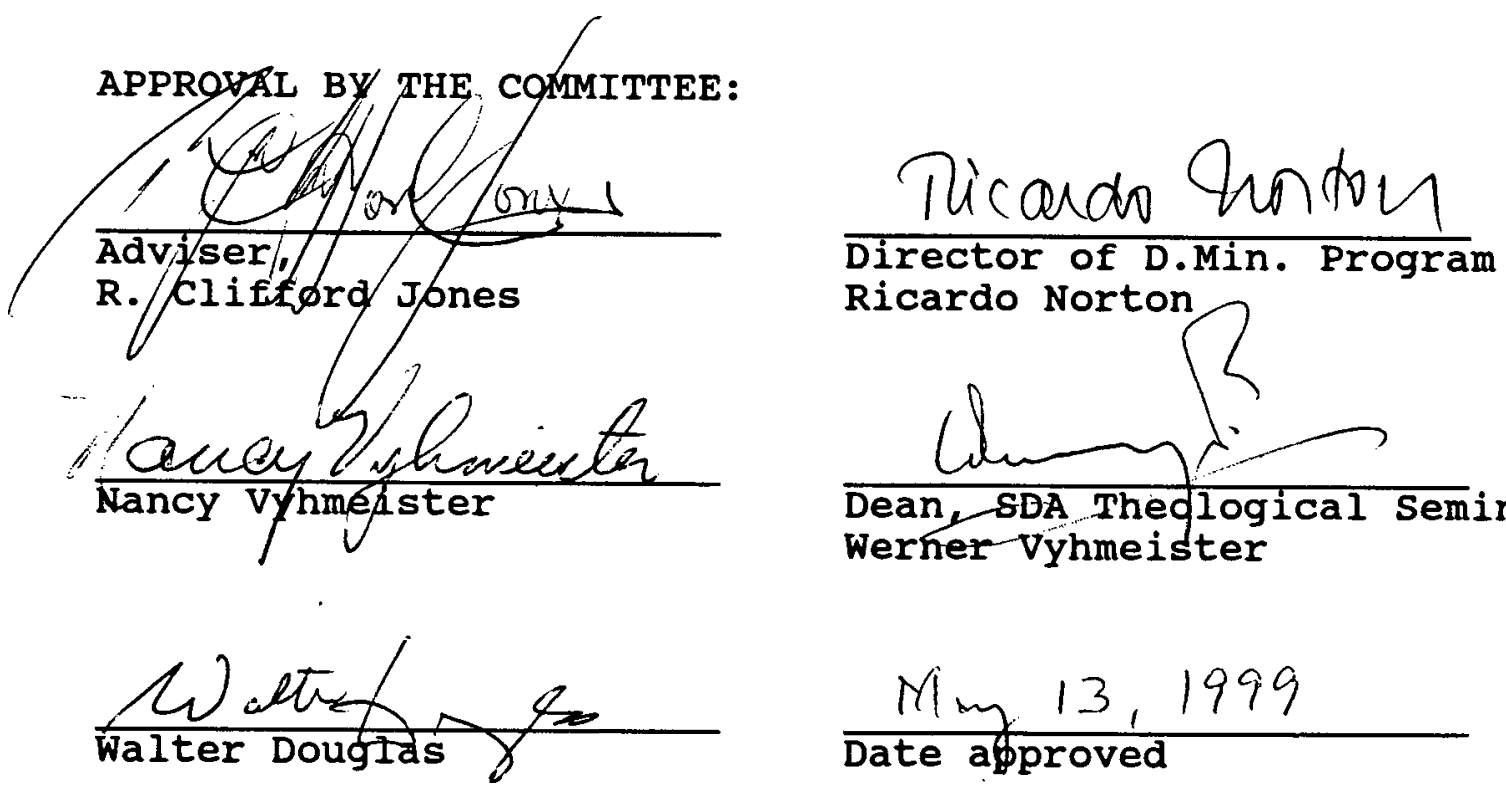
Ricardo Norton

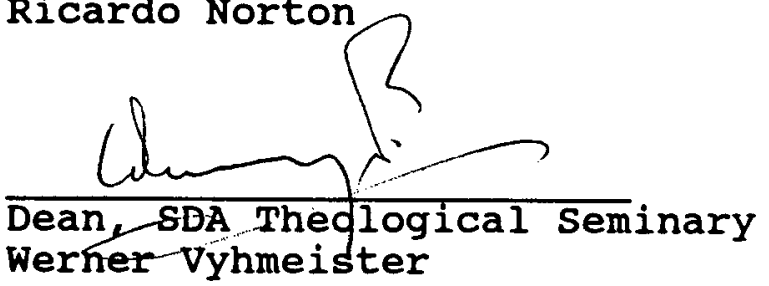

$\frac{\text { Ming } 13,1999}{\text { Date approved }}$ 
TABLE OF CONTENTS

Chapter

1. INTRODUCTION . . . . . . . . . . . . . . 1

Problem . . . . . . . . . . . . . 2

statement of the Task . . . . . . . . . 2

Justification for the Project . . . . . 2

Description of the Problem . . . . . . 3

2. HOMELESSNESS . . . . . . . . . . . . . 5

Defining Homelessness . . . . . . . . 5

Why People Become Homeless . . . . . . 8

Number of Homeless People in London . . . 12

Conditions Faced by Those who Sleep Rough 17

Poverty . . . . . . . . . . . 17

Cold . . . . . . . . . . . . . 19

Mental Illness . . . . . . . . . 20

Hunger . . . . . . . . . . . . . 21

Urgent Needs of the Homeless . . . . . 23

What Is Being Done for the Homeless? . . 26

Conclusion .............. 30

3. A BIBLICAL RATIONALE FOR MINISTRY TO THE POOR 31

Introduction . . . . . . . . . . . 31

The Exodus . . . . . . . . . . . 31

Law of Release . . . . . . . . . 36

Word study . . . . . . . . . . . 37

Background of the Passage . . . . . 40

Analysis of the Text . . . . . . . 42

Interpretation of the Text . . . . . 45

Matt 25:31-46 . . . . . . . . . . . . 47

Analysis of the Passage . . . . . . 48

Son of Man . . . . . . . . . . . . 48

The Brethren . . . . . . . . . . . . 50

Luke $4: 17-20$. . . . . . . . . . 56

Conclusion .............. 62

4. ELLEN WHITE'S CONCERN FOR THE POOR . . . . . 64

Personal Traits of Character . . . . . 65

External Factors Which Cause Poverty . . 66 
What should Be our Attitude to the Poor? 67

Who Are the "Deserving Poor"? . . . . 69

The Church and the Poor . . . . . 70

Biblical Basis for Her Arguments on the Poor 73

Conclusion . . . . . . . . . . . . 80

5. A STRATEGY FOR MINISTRY TO THE POOR IN

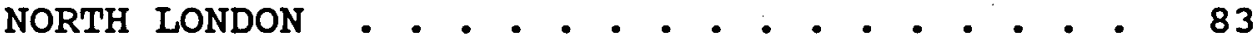

The Adventist Church in North London . . 83

The strategy . • . . . . . . . . . 85

Analysis . . . . . . . . . . . 90

Goals . . . . . . . . . . . . 93

Description of the strategy . . . . . 95

Sermons to Sensitize, Empower, and

Motivate the Church . . . . . . 95

Discussion Groups . . . . . . . . 96

Meetings with Organizations . . . . . 97

other Religious Organizations . . . . 98

Meetings with Government Organizations 98

Practical Plans for Implementing the

Strategy . . . . . . . . . . . . . 99

Bridge People . . . . . . . . . . 100

Drop-In Center . . . . . . . . . . . 101

Resources . . . . . . . . . . . . . . 102

Evaluation . . . . . . . . . . . . . . 104

Conclusion . . . . . . . . . . . 105

6. SUMMARY, CONCLUSION, AND RECOMMENDATIONS • • 107

Summary . . . . . . . . . . . . . 107

Recommendations . . . . . . . . . . 108

Conclusion . . . . . . . . . . . . 110

Appendix

A. QUESTIONNAIRE • . . . . . . . . . . . . 114

B. MY BROTHER'S KEEPER . . . . . . . . . . . . 119

C. GUIDELINES FOR DISCUSSION ON ELLEN WHITE'S

TEACHINGS ON THE CHURCH'S RESPONSIBILITY

TO THE POOR 


\section{ACKNOWLEDGMENTS}

I thank God for $\mathrm{His}$ love and care over me during the writing of this project. I would like to thank the members of the committee: Dr. R. Clifford Jones, Dr. Nancy Vyhmeister, Dr. Walter Douglas, and Dr. Ricardo Norton for their valuable suggestions, without which this project would not have reached this stage. I would like to thank the Mission Department and the Seminary Financial Committee or financial support. I thank my mother, Evelyn Thorpe, for her encouragement and her prayers. I thank Dr. Bridget Tucker Gonder for her invaluable support during the writing of this project. I would like to thank the ladies of the Halloway Church for their support and financial assistance. I would like to thank my sons, Carlos and Fabian, for their help and support. I express my profound thanks to Bonnie Beres for typing and editing the project. 
CHAPTER 1

\section{INTRODUCTION}

My concern for inner-city ministry began when I was called to work in the East Jamaica Conference of Seventh-day Adventists in 1981. For six years I worked with the poor and I made attempts to meet their needs. I became aware that the Seventh-day Adventist Church in Jamaica did not have a strategy for ministering to the needs of the poor. It seemed to me then that food baskets at Christmas were not the answer to the needs of the poor.

During nine years of ministry in London, I became aware that there are people who "sleep rough," that is, on the street. I have spent many nights walking the streets of North London talking with people who are homeless. I have tried to meet some of the needs of those who sleep rough, but the task seems almost impossible because of limited personal resources.

While the church in North London makes sporadic attempts to deal with the needs of the poor, there is need for a consistent ministry to the poor. In order to establish this ministry to the poor, there will be a need 
for re-ordering of priorities both at the local church and conference level:

\section{Problem}

Despite the benefits that the English Social Security provides, many individuals fall out of the safety net into abject poverty. Every night hundreds of individuals sleep rough. Exposed to the elements, these people are in need of food and a permanent place. The Seventh-day Adventist Church in North London is not providing an adequate ministry to meet the physical and spiritual needs of these people.

\section{Statement of the Task}

The task of this dissertation is to develop a strategy for ministry to the physical and spiritual needs of those who "sleep rough" in North London.

\section{Justification for the Project}

1. People who sleep rough urgently need a ministry which will meet their physical and spiritual needs.

2. The Seventh-day Adventist church members in North London need a consistent ministry for people who sleep in the streets.

3. This project will enhance my ministry to the poor and needy.

4. This project could help other ministers in the South England Conference to develop ministries to the poor. 
5. This project could provide a model for innercity ministries in the South England Conference.

6. There is no known study which has provided a strategy for dealing with those who sleep in the streets of North London.

\section{Description of the Problem}

Chapter 2 looks at various aspects relating to homelessness, defines homelessness, looks at causes of homelessness, explores conditions faced by a specific class of homeless, those who sleep rough, and suggests urgent needs faced by those who sleep on the street. It also considers what is being done to help those who sleep on the street.

Chapter 3 looks at a biblical rationale for ministry to the poor. Two passages are taken from the old Testament: the Exodus and the Law of Release (Deut 15:1-11). Two come from the Gospels. In Matt 25:31-46, Jesus sets out the standard for judgment of the nations. In Luke 4:17-20, Jesus uses the Jubilee motif to point to a central aspect of His ministry. The event of the exodus is looked at through the eyes of selected liberation theologians. The Law of Release is approached through a word study. The other two passages are analyzed exegetically.

Chapter 4 looks at Ellen White and the poor. It considers her reasons for poverty, especially personal traits of character and external factors. It presents the 
Christian attitude towards the poor. The chapter concludes with the biblical basis for her teaching on the poor.

Chapter 5 suggests a strategy that can be effective in meeting the needs of those who sleep on the streets of North London.

Chapter 6 provides a summary and conclusion with recommendations that are necessary for the implementation of the strategy to benefit those who sleep rough in North London. 
CHAPTER 2

HOMELESSNESS

This chapter looks at various aspects relating to homelessness: it defines homelessness, looks at causes of homelessness, explores conditions faced by a specific class of homeless, those who sleep rough, and suggests urgent needs faced by those who sleep on the street. It also considers what is being done to help those who sleep on the street.

\section{Defining Homelessness}

It is important for this study to define homelessness because it is vital to establish a working definition. It is also vital to limit the class of homelessness with which this study is concerned, and to clarify some commonly held misconceptions.

To many individuals, being homeless is defined as sleeping on the street. Even though sleeping on the street is the most visible and severe form of homelessness, there are many other types of homelessness. ${ }^{1}$ 1998): 1 .

\footnotetext{
"Homeless, Poverty, and Health," Crisis 17 (July
} 
In London there are six distinct sub-groups into which the homeless can be categorized: people living rough on the street, people sleeping in hotels and night shelters, people sleeping in bed and breakfast, people living on squats, people with no fixed abode, those who are in hospitals and police cells, and the hidden homeless.'

An important definition for homelessness states that a homeless person is someone who does not have a home. It clarifies this statement by suggesting that "homeless people unlike other members of our society have either no accommodation or no permanent or settled accommodation, nowhere to call home."2

If we should examine the government definition of homelessness we will find that in its attempt to be exact, it excludes some of those who most need shelters.

The British legislative definition of homelessness - . is very precise. It describes and determines those who are homeless and those who are not, implementing in policy very rigid criteria. The definition, originally outlined in the 1977 Housing (Homeless Person's) Act and now incorporated in part iii of the 1985 Housing Act, was an attempt to address the issue of homelessness by concisely defining for local authorities those people for whom they have a legal obligation to provide accommodation. . . The intention of the Act was to insure that families with children would be assured of accommodation. However, young and/or single adults are not normally accepted or

'Jeanne Moore, David Carter, and others, The Faces of Homelessness in London (Altershot: Gower, 1995), 31.

${ }^{2}$ Ron Bailey, Homelessness: What Can We Do? (Oxford: Carpenter, 1994), 22 . 
defined as homeless by the Act and, thus, are unlikely to be housed.'

In further seeking to define homelessness we turn to the "commonsensical" definition. It divides homelessness into two categories: those who are homeless and those who are potentially homeless. The homeless are those individuals who are without shelter and sleeping rough, those who are in temporary accommodation, those who are in tied accommodation or insecure tenure, including squatters and those who are discriminated against in their effort to obtain housing because of race or gender. The potential homeless include those to be released from prison and psychiatric hospitals. ${ }^{2}$

The specific definition of homelessness with which this study is concerned is that of those who sleep rough on the streets. Rough sleepers can be divided into four categories: constant rough sleepers, those who sleep rough at all times (32 percent); regular rough sleepers, those who do so seasonally or on weekends ( 6 percent); occasional rough sleepers, those who sleep spasmodically (30 percent); and new rough sleepers, those who started sleeping rough within the previous seven days ( 7 percent).$^{3}$

\footnotetext{
${ }^{1}$ Kristina Downing-orr, Alienation and Social Support (Hants: Cower, 1996), 13.

${ }^{2}$ Ibid., 16 .

${ }^{3}$ Moore, Carter, and others, 58.
} 
Why People Become Homeless

There are many reasons why people become homeless.

For example, single homeless people suggest two main reasons why people sleep rough. The most important is that accommodation is not available. "Emergency hostels fill up quickly because people stay longer than it was intended for them to stay."1 The second reason why people become homeless is that people cannot afford to rent accommodations. "Single homeless people and couples without children are not entitled to a permanent home under the current housing legislation; they usually have to rely on the private rented sector."2

An often-neglected reason why some young people become homeless is the tendency for them to seek their independence. The change from adolescence to adulthood drives these young people to leave home and move towards the $\operatorname{city} \cdot^{3}$

Some of the major causes of homelessness come about because of political decisions, for example, the Housing Act of 1985. Between 1980 and 1991, there have been at least fourteen cuts in benefits for young people. These changes were enacted partly because of the conservative government's

'Joseph Oldman, ed., "Homelessness--What's the Problem?" Shelter (1994): 7 .

${ }^{2}$ Ibid.

${ }^{3}$ Downing-orr, 18 . 
position, which emphasized that parents should take responsibility for their children and that young single adults should remain at home with their parents. ${ }^{1}$

The Social Security Act of 1986, which came into effect on 11 April 1988, reformed the entire benefits legislative structure. For example, the single young adult contribution was made into one, so that young single adults who leave home received the same benefits as those who stayed at home. ${ }^{2}$

Another significant way that the Social Security Act contributes to homelessness is that income support is paid two weeks in arrears. While individuals are waiting for their benefits, they must find alternate sources of financial support. Usually when they receive their benefits these are used to repay debts.

The prime minister of the United Kingdom, Tony Blair, commenting on homelessness in London, said that homelessness is "a symbol of our divided society, of the failures of policies aimed at the few." ${ }^{3}$ While the prime minister may have been right in his suggestion of one of the causes of homelessness, one important situation that has influenced homelessness in the United States is that there

$$
\begin{aligned}
& { }^{1} \text { Ibid., } 10 . \\
& { }^{2} \text { Ibid., } 19 .
\end{aligned}
$$

${ }^{3}$ Nick Hopkins, "Homeless Crisis Gets Street Tsar," The Guardian, 6 July 1988, 1 . 
is no official poverty line. The government does not admit the existence of poverty. ${ }^{1}$

In a recent report on the UK, the United Nations Human Development Report states:

Deprivation, chronic unemployment, and poor levels of literacy have turned the UK into one of the most poverty-stricken countries in the developed West. . . only the United states and Ireland among wealthy nations suffer from higher levels of poverty. ${ }^{2}$

While the government does not admit that there is poverty in England, the following excerpt from a letter from the Social Exclusion Unit, ${ }^{3}$ which is located in the cabinet office, seems to suggest that there is a change in the government's policy regarding those who sleep rough.

In the Social Exclusion Unit's first phase, the prime minister has asked us to look at the issue of rough sleeping, with the objective of reducing to as near zero as possible the numbers of people sleeping rough. - . We would like to invite you to send us your thoughts on how rough sleeping can be reduced. . . . It would be helpful if you could share with us any hard information you have about the characteristics of people sleeping rough, the causes of rough sleeping. We should also welcome comments direct from people who are or have been, sleeping rough and should be grateful for anything you can do to encourage this.4

${ }^{1}$ Carey Oppenheim, "Poverty in London: An Overview," Child Poverty Action, December 1994, 6 .

${ }^{2}$ Larry Elliott, "Britain's Poor Are Worse off Than Ever," The Guardian, 9 September 1998, 1-3.

${ }^{3}$ This Unit was given the task of tackling "the greatest social crisis of our time," which is to find a solution for those who are not able to participate in the economic, social, and political life of Britain.

${ }^{4}$ Patricia A. Wapple, "People Sleeping Rough," Sleeping Rough, February 1997, 1. 
Another evidence of change in the government's policy can be seen in the prime minister's promise of 800 million pounds to narrow the gap between "the two Britains," one that is rich and affluent and the other that lives in poverty. ${ }^{1}$ The prime minister rightly recognized that the narrowing of the gap between "the two Britains" will not come about by injecting capital into the program. He admits that in the past some projects that were intended to bring about social change have failed. However, he hopes that his new plan will bring about the change that will create a new Britain.2

The reasons why people sleep rough are complex and there does not seem to be any single explanation. A survey conducted by London Outreach Team shows that 24 percent of those who sleep rough did not like the accommodation; 23 percent had drinking problems; 17 percent had financial problems; 15 percent experienced breakdown in relationships; 5 percent were evicted; 4 percent had psychiatric problems; and 17 percent reported other problems. ${ }^{3}$

One area in which the impact of financial problems can be seen among the homeless is in the areas of mortgage arrears and repossessed houses. "During 1993 a total of

\footnotetext{
${ }^{1}$ Peter Hetherington, "Blair Pledges Program to
} Bridge the Gap between Rich and Poor," The Guardian, 16 September $1998,1-2$.

${ }^{2}$ Ibid., 2 .

${ }^{3}$ Moore, Carter, and others, 58 . 
49,210 properties were repossessed. At the end of 1994, 419,890 home owners were in mortgage arrears. In the first half of $1995,37,631$ possession orders were made out against home owners."1

While agreeing that there are many reasons why people become homeless, the Charity Crisis suggests that "the root cause of homelessness is the lack of decent affordable housing in the areas where people want and need to live." 2

\section{Number of Homeless People in London}

Table 1 looks at poverty over a long-term period (1960-1987). It shows poverty defined and the basis of supplementary benefit. During the period under review it suggests that while there was an increase in income, this did not significantly affect those living below the poverty line. There were signs of fluctuation but there was no significant decline among those living in poverty.

In 1960 only 7.2 percent of the population was living in poverty. By 1975 the figure was 10.5 percent and by 1987 poverty affected nearly a fifth of the population in. Britain: 18.8 percent or 10.2 million. Of those, 2.9 1995,22 .

"Homeless in England," Shelter, September 1995, 2.

"Place to Call My Own," Crisis-Shelter, December 
TABLE 1

EXTENT OF POVERTY IN BRITAIN, 1960-1987 (In Percentages)

\begin{tabular}{|c|c|c|c|c|c|}
\hline Year & $\begin{array}{l}\text { Below } \\
\text { assistance } \\
\text { level }\end{array}$ & $\begin{array}{l}110 \% \text { of } \\
\text { assistance }\end{array}$ & $\begin{array}{l}\text { Below } 120 \% \\
\text { of assistance }\end{array}$ & $\begin{array}{l}\text { Below } 140 \% \\
\text { of assistance }\end{array}$ & $\begin{array}{l}\text { Proportion of } \\
\text { persons in } \\
\text { recepit of } \\
\text { assistance } \\
\text { benefit }\end{array}$ \\
\hline 1960 & 3.8 & 6.6 & 9.0 & & 14.2 \\
\hline 1967 & 3.5 & & & & \\
\hline 1972 & 3.4 & 5.5 & & & 7.7 \\
\hline 1973 & 3.0 & 5.9 & & & 7.1 \\
\hline 1975 & 3.0 & 4.8 & & & 6.1 \\
\hline 1977 & 4.0 & 6.0 & 7.0 & & 8.2 \\
\hline 1979 & 4.0 & 6.2 & 9.0 & 14.4 & 7.6 \\
\hline 1981 & 4.9 & 7.8 & 11.2 & 16.9 & 9.1 \\
\hline 1983 & 5.2 & 8.5 & 11.7 & 19.1 & 11.4 \\
\hline 1985 & 4.5 & 7.0 & 9.3 & 15.6 & 12.9 \\
\hline 1985(a) & 5.1 & 7.8 & 10.6 & 16.0 & 12.9 \\
\hline 1987 & 5.3 & 7.7 & 10.2 & 14.9 & 13.5 \\
\hline
\end{tabular}

Source: Vic George and Irving Howards, Poverty Amidst Affluence (Aldershot: Edward Elgar, 1991), 26. 
million, or 5 percent of the population, were living below the poverty line. ${ }^{1}$

In attempting to establish how many homeless people there are in London, we must recognize that there is no accurate count. Several factors contribute to this lack of a definite figure. Among these factors are that many homeless people do not participate in the government census. Further, homeless people do not have a permanent address. Finally, there are differences between organizations as to what constitutes homelessness.

There are nearly 150,000 people officially classed as homeless in the priority classes. These are mainly homeless families. Recently the Young Homeless Group estimated that in one year 156,000 young people between the ages of sixteen and twenty-five sleep rough on the streets, in railway sidings, squats, derelict buildings, on floors and the like. A recent report by Age Concern states that there are around 2000 people over the age of fifty living on the streets and in hostels in London. ${ }^{2}$

The statistics quoted above are a good example of the lack of precise data about homelessness in England generally. It is not clear if the "official figure" of 150,000 should be added to the 156,000 young homeless people. If one should take these figures at face value it would seem that there are about 306,000 homeless people in England.

\footnotetext{
${ }^{1}$ George and Howards, 27.

${ }^{2}$ Bailey, 2 .
} 
Because of the urban drift it has been estimated that there are more homeless people in London than in other parts of the country. In 1991 there were 22,383 single homeless persons in London, compared to 37,759 in the rest of the country.1

While there are no official statistics on homeless people in Britain, there are estimates of how many people sleep rough: 8,600 people every night. The 1991 census counted 453 sites where people sleep rough. This accounted for 2,703 people. of these, 1,275 were sleeping rough in London. ${ }^{2}$

Two preliminary conclusions can be drawn from the data in the 1991 census. The census implicitly recognized its limitation by mentioning that it counted 453 sites. There could have been other sites which were not counted. The second point is that the majority of people who sleep rough appear to be concentrated in London.

A significant factor that keeps organizations from arriving at an accurate number of homeless people is the various categories which fall under the umbrella of homelessness. Among these categories are those who do not have a roof over their heads, those who live in hostels, and those who sleep rough. It is not usually clear which category of homeless person is being referred to.

\footnotetext{
${ }^{1}$ Ibid.

${ }^{2}$ oldman, 6 .
} 
The Medical Campaign Project has made an attempt to establish a difference between two categories of homelessness. It estimates that there are 60,000 homeless in London. From these 60,000 there are 11,000 who sleep rough. 1

A more practical way of arriving at the approximate number of rough sleepers in London would be to count the number of meals that charities who work with the homeless distribute. An anonymous rough sleeper reports that three main groups distribute soup to those who sleep rough: the Hare Krishnas, the Seventh-day Adventists, and the Salvation Army. He estimates that "up to two hundred dinners are served each night." 2

The Halloway Seventh-day Adventist Church in North London estimates that it distributes an average of 400 meals on the second sunday of each month. It seems reasonable to conclude that in the areas targeted by this project there are approximately 400 individuals who sleep rough. ${ }^{3}$

The suggested figure of 400 people sleeping rough is near to the figure which came from a survey taken in November 1991, which found that there were 419 people

\footnotetext{
${ }^{1}$ Nick Fielding, "Is There a Doctor in the House?" New Statesman and Society, 9 September 1988, 31.

${ }^{2}$ Editorial, "The Homeless Move Along," The Economist, 6 February 1993, 65.

${ }^{3}$ Halloway Seventh-day Adventist Church Minutes, 4 December 1984 .
} 
sleeping rough in central London; most of these were found in the Fields, in neighboring kingsway, the strand, and around Waterloo station. ${ }^{1}$

The literature reviewed suggests that there is some difficulty in arriving at an exact number of people who are homeless and sleep rough. However, there are hundreds of individuals. In the target area of this project, which is near the Embankment at the strand, there seem to be approximately 400 rough sleepers.

\section{Conditions Faced by Those who sleep Rough}

\section{Poverty}

one of the major conditions faced by people who sleep rough is poverty. George and Howards suggest that definitions of poverty are usually subjective and influenced by individual expectations. They argue that if someone has minimal requirements for poverty, his expectation will be minimal. If, on the other hand, one has modest requirements for poverty, one's expectations will be modest. ${ }^{2}$

Four definitions of poverty have been used to define levels of poverty. The first and most austere definition equates poverty with starvation. With this definition a person is living in poverty if he does not have money or

\footnotetext{
${ }^{1}$ Editorial, 65.

${ }^{2}$ George and Howards, 1 .
} 
enough resources to obtain food needed to avoid undernourishment. ${ }^{1}$

The second definition of poverty is concerned with subsistence. A person is considered to be living in poverty if his income and resources are not sufficient to pay for a small number of requirements at the basic level in terms of quantity and quality. ${ }^{2}$

The third definition of poverty is related to social coping. People are in poverty if their income or resources are not sufficient to provide those goods and services that will enable them to live a life tolerable according to the working class. ${ }^{3}$

The fourth definition, social participation, defines poverty in terms of and in relation to the prevailing living standard. The level of requirement is considered to be very modest. ${ }^{4}$

Most people who sleep rough live below the subsistence level. These individuals are not able to cope socially. They live below acceptable standards. These people do not have the money or the resources to get food. Life expectancy for those who live and sleep on the street is shorter than the average life expectancy in

\footnotetext{
${ }^{1}$ Ibid., 3 .

${ }^{2}$ Ibid., 4 .

${ }^{3}$ Ibid. , 6 .

${ }^{4}$ Ibid., 7.
} 
Britain. The Homeless Charity Crisis suggests that people sleeping rough in London and who die of natural causes live to an average age of forty-six years, which is thirty years younger than the national average life expectancy. ${ }^{1}$

\section{Cold}

Another of the conditions faced by those who sleep rough is the cold. Prolonged exposure to the cold makes people in general, and especially those who sleep on the street, prone to severe cold-related conditions such as frostbite, frost nip, hypothermia, chilblains, and trench foot. 2

Some of these cold-related illnesses are dangerous. If the temperature falls to four degrees Centigrade, there is the danger of damage to the body. Frostbite occurs when the skin is frozen to the extent that the cells are damaged. The cells can be so damaged that they cannot be repaired; when this occurs one can lose the affected areas (nose, fingers, or ears). ${ }^{3}$

Hypothermia is life-threatening. This cold-related illness occurs when one is exposed to the cold for some length of time. The body temperature drops. The organs of

${ }^{1}$ Meikle James, "Homeless: Deadly Serious Having No Home Is Not Just Distressing--It Can Be Fatal," Guardian, 10 December 1997.

${ }^{2}$ National Council of YMCA, "If You Are Homeless," YMCA, November 1997 , 3.

$$
{ }^{3} \text { Ibid. }
$$


the body draw blood from the skin so that it loses sensation, while the pulse and breathing become weaker and weaker until eventually the heart stops pumping altogether. The effect of the cold on those who sleep rough is described as follows. The number of homeless people attending Westminster Hospital in 1994 tripled during the cold snap early in the year. "Gangrene, frostbite and hypothermia were just some of the complaints." sleeping in the streets of London during the winter can lead to death. ${ }^{2}$

A rough sleeper described cold as probably the biggest problem for those who sleep on the street. He also describes how he deals with the problem. "You just go off and get drunk. It is easier to get to sleep when you are drunk or stoned. You wake up in the morning and you are a lot colder, and then another drink warms you up."3

\section{Mental Illness}

There is a growing number of mentally ill persons among those who sleep rough. On the one hand, it has been suggested that one of the contributing factors to the increase of mentally ill people sleeping on the street is the government policy of "care in the community." on the

IIbid., 5.

${ }^{2}$ Trevor McDonald and Michael Lawrence, eds., "Cold Kills!" LBC's Public Affairs Forum, 1994, 8.

${ }^{3}$ Ibid. 
other hand, it has been argued that "mental illness is often the effect of homelessness as much as the cause."1.

While some individuals end up on the street as the result of mental illness, for others, mental illness results from losing their homes and other related or personal problems. "For example, losing your job, losing your partner or your child and then once you are on the street, the very stressful lifestyle of just trying to survive day to day can also cause mental ill-health."2

The mentally ill are the most vulnerable members of the homeless population. It is hard for them to get jobs and they do not make friends easily. They find it hard to trust people, and they are not good at putting themselves forward to the Social services from which they could obtain benefits. ${ }^{3}$

\section{Hunger}

The need for food is one of the factors which contributes to ill health among those who sleep on the street. During the winter months, those who sleep on the street need food that will provide them with energy and body heat. At all times these individuals need a balanced diet which can provide them with necessary nutrients.

$$
\begin{array}{ll}
{ }^{1} \text { Ibid., } & 17 . \\
{ }^{2} \text { Ibid., } & 18 . \\
{ }^{3} \text { Ibid., } 17 .
\end{array}
$$


On the one hand, the British will not admit that there are individuals in Britain who do not have food to eat. They adopt the position that "the poor in Britain are not like the poor in Asia, Latin America, or Africa."1 on the other hand, there are individuals in the underground with signs reading "Homeless and Hungry Please Help." There are mothers with babies begging for food. There are young people begging for food.2

Two significant activities can be directly attributed to the lack of food of those who sleep on the street. The first is the apparent increase in begging on the street. Those who beg on the street can be classified into three groups: professional beggars, those who beg to maintain a vice, and those who beg because they need food. It has been suggested that some professional beggars can get up to 1000 pounds a week $(\$ 1,500)$. Others get up to 85 pounds a day. On the other hand, some beggars hardly get anything. For example, one beggar reports that during a week he got only 3 pounds. ${ }^{3}$

Londoners have always been worried about being exploited by those who claim to be in need. In recent times the public and some pastors have condemned begging. One

'Conrad Boerma, The Poor Side of Europe (Geneva: wCC, 1989), vii.

${ }^{2}$ Andrew O'Hagan, "Down and Out in London," World Press Review, March 1994, 47.

$$
{ }^{3} \text { Ibid. , } 47 \text {. }
$$


pastor said that he was not aware of any part of the gospel that suggests that Jesus casually gave money to anyone who asked. Other individuals have described beggars as "layabouts, wasters and filthy idlers." while there might be some idlers and layabouts among those who beg on the street, many simply have no food.

The second activity is attending centers where food is distributed, or the "soup run." For example, the Salvation Army states that in an average year it distributes 50,000 meals, 44,000 food parcels, and 18,000 Christmas meals. ${ }^{2}$ While it is true that people usually gravitate towards food and some who come for food are not in dire need, it seems reasonable to conclude that many come for food because it is the only option open to them.

\section{Urgent Needs of the Homeless}

People who sleep on the street face many urgent needs. Among them are: adequate housing, medical care, food, clothing, knowledge of how to access social security, and skills to become employable.

The need for adequate housing is one of the most important faced by those who sleep rough. Proper housing not only provides shelter from the cold, it also provides the individual with an address. A permanent address is an

\section{${ }^{1}$ Ibid.}

${ }^{2}$ Salvation Army Social Services, "Salvation Army Facts," The Salvation Army Pack on Homelessness, 1997, 3. 
important asset. It enables the individual to get medical care by registering at the local general practitioner who provides the entrance into the health system. With a permanent address the individual is able to have a place where a social security check can be sent. A permanent address also provides the individual with an address when seeking for employment, because employers do not readily employ individuals who do not have a fixed address. ${ }^{1}$

While life expectancy is increasing among the general British population, it is declining among those who sleep on the street. One reason for the short life span among those who sleep on the street is the lack of medical care. There is an urgent need to help those who sleep on the street to access health care. ${ }^{2}$

During the cold months and because of the British weather, those who sleep rough urgently need warm clothing. For example, they need blankets, coats, thermal underclothes, and hats.

The government, through social security, makes funds available for those who are in need. For example, there are the Income support Benefits, which individuals or families can get to supplement their income. There is the "dole," which gives an allowance to individuals who have lost their

\footnotetext{
${ }^{1}$ Feilding, 31 .

${ }^{2}$ Andrew Haines, "Working Together to Reduce Poverty's Damage," British Medical Journal, 22 February $1997,529-530$.
} 
jobs or who have not been employed. But these benefits are difficult to get for those who are constantly on the move.' Some argue that those who sleep on the street are idlers who do not work or want to work. A survey commissioned by the Salvation Army shows that 50 percent of those who sleep on the street are unemployed; however, a third were doing some form of work including casual work. "A remarkable $20 \%$ were doing voluntary work."2 In any case, finding suitable work is high among the needs of the homeless.

The survey also showed that among those who sleep on the street there are individuals with various levels of education. For example, 45 percent did not have any education, 28 percent had CSE/GCE, 9 percent had a school Certificate, 7 percent had degrees, another 7 percent had other qualifications, 2 percent had professional

qualifications, and 2 percent had university entrance- level qualifications. ${ }^{3}$

There is an urgent need to provide facilities where those people sleeping on the street who are not employed can be trained to become employable. There seems to be a relationship between the 50 percent who are unemployed and the 45 percent who do not have any education.

\footnotetext{
${ }^{1}$ Ibid.

${ }^{2}$ Moore, Carter, and others, 72 .

${ }^{3}$ Ibid. , 73 .
} 


\section{What Is Being Done for the Homeless?}

The Salvation Army is the single major religious group which contributes to meeting the needs of those who sleep on the street in London. The purpose and aims of this religious group are described in its general mission statement.

The Salvation Army is an integral part of the universal Christian Church. Its message is based on the Bible; its motivation is the love of God as revealed in Jesus Christ. Its Mission is to proclaim His gospel, to persuade men and women to become His disciples and to engage in a program of practical concern for the needs of humanity. Its ministry is offered to all, regardless of race, creed, color, age or sex. ${ }^{1}$

A careful look at this general mission statement suggests that the Salvation Army intentionally sets out to minister to the whole person. Its ministry is for all people.

The Salvation Army Social Services Mission Statement further clarifies the commitment of this organization to work for the poor.

The Salvation Army, founded in London in 1865, is an international religious and social welfare movement and is a branch of the mainstream Christian Church. The motivation of the organization is a love of God and practical, caring concern for people in need regardless of race, color, creed, gender or age. Its objective is the physical, moral and spiritual regeneration of the people it serves through the provision of basic human necessities, counseling, living and preaching the Christian gospel.2

'The Salvation Army Social Services, "Mission statement of the Salvation Army," Salvation Army Information Pack on Homelessness, 1997, 2 .

${ }^{2}$ Ibid. 
The Social Services Mission statement expands on the General Mission statement. For example, it states that its objectives are physical, moral, and spiritual regeneration. This statement implies that this organization is concerned with more than providing food or shelter.

The Salvation Army has fifty-two centers for the homeless. These centers provide approximately 3,400 beds for men and women each night. They also have twenty-eight eventide homes, which provide 900 places. ${ }^{1}$

The Army also provides specialist centers where individuals can be treated for alcohol and other drugrelated illness. These facilities are able to accommodate up to 400 individuals. ${ }^{2}$

In keeping with one of the Salvation Army's objectives, which is to provide services for all those who are in need, the Army provides three children's homes which house approximately sixty children. ${ }^{3}$

Since 1991, the Salvation Army has been involved in the Rough Sleepers Initiative in London. In cooperation with government and other agencies, they are enabling homeless people to become established in long-term

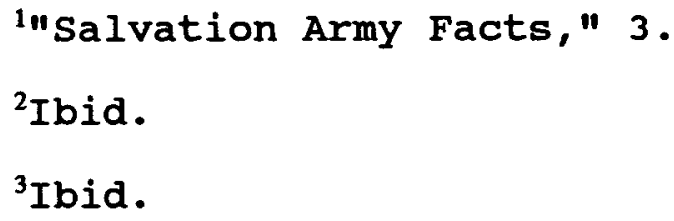


accommodation. They provide the support system that will help rough sleepers to break the cycle of homelessness. ${ }^{1}$

Another important and vital service that the Salvation Army provides is food for individuals who sleep rough. They distribute approximately 50,000 meals each year. They are known for their "soup run," in which they take food to those who are sleeping rough. ${ }^{2}$

The Hare Krishna are involved in providing food for those who sleep on the street. They seem to have a regular pattern of distribution. However, it is difficult to calculate the volume of their work because they do not keep accurate records of the number of meals distributed. It seems that they believe one should not keep records of good done to others.

The Children's Society, which is a Church of England voluntary society, does a significant job with homeless children. This organization is partly responsible for providing for the approximately 224,000 homeless children in England. They are partly responsible for the fact that in London there are no children among those who sleep on the street. ${ }^{3}$

\footnotetext{
${ }^{1}$ Ibid., 5.

${ }^{2}$ Ibid., 3 .

${ }^{3}$ Amanda Allard, "Briefing on the Extent and Causes of Homelessness," The Children's Society, June 1997, 1.
} 
One area in which there is significant cooperation among religious groups is the "soup run." For example, volunteers from Christ Church, Cockfoster (Church of England); Finsbury Park and Southgate Methodist Circuit; and the Hyde United Reformed Church in Colindale all participate with the "soup run."1

Soup runs are not restricted to volunteers from church organizations. Some secular organizations also participate as, for example, youth clubs, young people who are working on the Duke of Edinburgh Gold Award Scheme, and social workers from E.C., Eastern Europe, and Iceland.2

Local businesses contribute to the "soup run" by donating food. Among the businesses that contribute to this venture are Boots, a nationwide chain of chemists; Marks and spencer, a national chain of clothing and food stores; and Bloomsbury, a regional chain of restaurants. ${ }^{3}$

The British Army also contributes food to the "soup run." It donates food from the leftovers from social occasions such as parties and receptions. These leftovers are called "Sally-Ann."4

\footnotetext{
${ }^{1}$ Raymond J. Dickinson, "The Helpers," The Regent Hall Soup Run, 1997, 6-7.

${ }^{2}$ Ibid., 7 .

${ }^{3}$ Ibid.

${ }^{4}$ Ibid.
} 


\section{Conclusion}

Hundreds of individuals sleep on the streets of London. Those who sleep on the street have urgent needs. Among these needs are: food, clothing, medical care, access to the social security system, and having a permanent address.

While some organizations are providing for some of the needs of those who sleep rough, there is a great need for a coordinated and consistent effort that will provide for these individuals. 
CHAPTER 3

A BIBLICAL RATIONALE FOR MINISTRY

TO THE POOR

\section{Introduction}

Several biblical passages could be used to establish a biblical rationale for ministry to the poor. However, I have selected the following passages because of the scope and message that they represent. Two are taken from the old Testament: the Exodus and the Law of Release (Deut 15:111). Two come from the Gospels: in Matt 25:31-46, Jesus sets out the standard for the judgment of the nations; in Luke 4:17-20 Jesus uses the Jubilee motif to point to the central aspect of His ministry. The event of the Exodus is looked at through the eyes of selected liberation theologians. The Law of Release is approached through a word study. The other two passages are analyzed exegetically.

\section{The Exodus}

The Exodus was God's first act of mass deliverance from oppression. The Exodus demonstrates that God is not only concerned about the individual cry but hears the collective cry of the oppressed. In this section we look at 
the Exodus through the eyes of selected liberation theologians.

James Plastars points out that the Exodus is not only central to Jewish faith, but it is also a dramatic account of Yahweh's intervention on behalf of the oppressed. He further suggests that the Exodus was the moment when faith began for the Hebrews. It was this faith which shaped Israel's understanding of history.

Israel's oppression began after the death of a pharaoh who was sympathetic to their cause. With the coming of a new pharaoh they were subjected to bondage and ultimately enslaved. So great was this enslavement that the people cried unto God. God heard their cry and remembered the covenant He had made with their fathers. Exod 3:7-10 describes God's response to the condition that Israel was experiencing:

Then said Yahweh, I have seen the affliction of my people who are in Egypt and their cry I have heard because of their task masters. I know their suffering, and I have come down to deliver them out of the hand of the Egyptians and to bring them up out of that land to the land flowing with milk and honey. And now behold the cry of the people of Israel has come to Me and I have seen the oppression with which the Egyptians oppress them and now come, I will send you to Pharaoh that you may bring forth my people, the sons of Israel, out of Egypt.

Jose Comblin suggests that the cry of the people was not just a shout but an address to God with the expectation

\footnotetext{
'James Plastars, The God of Exodus (Milwaukee, WI: Burce, 1966), 7.
} 
that He would respond. He argues that the word "cry" could better be understood as an "outcry." The Hebrew saag is a technical term which describes a helpless person calling for assistance in the face of injustice. ${ }^{1}$

God's miraculous response to the plight of His people in Egypt is a constant reminder that He is concerned about those who are oppressed. The repeated reminders in Scripture that the Israelites were slaves in Egypt were not to remind them of slavery, but to remind them of how God had led them with a mighty hand from oppression.

The relevant question for which we should seek an answer is, Is God still concerned about the plight of the oppressed and the poor? Should the poor and the oppressed be allowed to fight for themselves? How does God intervene in the world today? It seems to me that God's mass deliverance during the Exodus is a sign that God intervenes in the affairs of humankind. Because God does not change, He continues to care about the plight of those who are oppressed.

Two main ways have been taken to describe how God intervenes in the plight of those who are oppressed in contemporary society. On the one hand, there are those who wait for the second coming of Jesus, when all things will be made new. On the other hand, there are those who confront

\footnotetext{
'Jose Comblin, Cry of the oppressed, Cry of Jesus (New York: Orbis, 1988), 4-5, 28.
} 
oppression and poverty by looking at the cause and the institution that perpetuates them. Among those who argue that sin in the structures of society should be confronted is Leonardo Boff. He suggests that when theologians are faced with oppression, the first question that they should ask is, Why is there oppression and what are its causes? ${ }^{1}$ Commenting on God's intervention through the Exodus, Severino Croatto states that because oppression in Egypt was politically introduced and maintained, the liberation from Egypt was a political and social event. God was concerned not only about spiritual liberation, He was interested in liberating the total person. ${ }^{2}$ While emphasizing the political nature of the Exodus, Croatto makes an unsuccessful attempt to maintain a balance between the political and the religious aspects. He implies that it would not be practical to expect that God would intervene in contemporary society, as He did in Egypt. Therefore, the use of the political option is justified in the pursuit of liberation. ${ }^{3}$

Atilio Dupertuis, while agreeing that the Exodus story describes God's response to the cries of the oppressed, disagrees with the political position taken by

\footnotetext{
${ }^{1}$ Leonardo Boff and clodovis Boff, Introducing Liberation Theology (New York: Orbis, 1987), 25.

${ }^{2}$ Severino Croatto, Exodus: A Hermeneutics of Freedom (New York: Orbis, 1981), 18 .

${ }^{3}$ Ibid., 22 .
} 
liberation theologians. He suggests that some liberation theologians have focused on the peripheral agents of liberation such as civil disobedience, which usually leads to violence. He argues that the central message of the Exodus, which is the deliverance of the suffering and the powerless, can be obscured in emphasizing militant action. ${ }^{1}$ One of the dilemmas that Exodus scholars must confront is how to relate the Exodus story to current injustice and oppression. It is possible to take the position that the Exodus story is only a record of God's dealing with His people in the past, and that it does not relate to current situations and cannot be used as a model for current situations.

Liberation theologians who take the position that the Exodus provides a paradigm through which they can relate to current injustice arrive at their conclusions by use of Marxist analysis.

The Exodus account does provide a model for deliverance from injustice and oppression, while there may be times when civil disobedience might be necessary in order to achieve justice and freedom. This study takes the position that it is necessary to alleviate the plight of the hungry and the needy by ministering to their needs within the oppressive system.

${ }^{1}$ Atilio Rene Dupertuis, Liberation Theology: Use of the Exodus, A Soteriological Model (Berrien Springs, MI: Andrews University Press, 1982), 310. 


\section{Law of Release}

At the end of every seven years thou shalt make a release.

And this is the manner of the release: Every creditor that lendeth ought unto his neighbor shall release it; he shall not exact it of his neighbor, or of his brother; because it is called the Lord's release. of a foreigner thou mayest exact it again: but that which is thine with thy brother thine hand shall release; Save when there shall be no poor among you; for the Lord shall greatly bless thee in the land which the Lord thy God giveth thee for an inheritance to possess it: only if thou carefully hearken unto the voice of the Lord thy God, to observe to do all these commandments which I command thee this day.

For the Lord thy God blesseth thee, as he promised thee: and thou shalt lend unto many nations, but thou shalt not borrow; and thou shalt reign over many nations, but they shall not reign over thee. If there be among you a poor man of one of thy brethren within any of thy gates in thy land which the Lord thy God giveth thee, thou shalt not harden thine heart, nor shut thine hand from thy poor brother: But thou shalt open thine hand wide unto him, and shalt surely lend him sufficient for his need, in that which he wanteth. Beware that there be not a thought in thy wicked heart, saying, The seventh year, the year of release, is at hand; and thine eye be evil against thy poor brother, and thou givest him nought; and he cry unto the Lord against thee, and it be sin unto thee. Thou shalt surely give him, and thine heart shall not be grieved when thou givest unto him: because that for this thing the Lord thy God shall bless thee in all thy works, and in all that thou puttest thine hand unto. For the poor shall never cease out of the land: therefore I command thee, saying, Thou shalt open thine hand wide unto thy brother, to thy poor, and to thy needy, in thy land. (Deut 15:1-11)

In order to clarify the meaning of the passage above, we look at some key words: "poor," "release," and "brother." We begin by looking at several words in the old Testament which describe various categories of "poor." However, our main concern will be the content in which "poor" is used in the Pentateuch. 
Word study

The old Testament uses seven words to describe categories of poor: ebyon (the beggarly poor), dal (the poor peasant farmer), mahsor (the lazy poor), mishem (poverty), ras (political and economic inferiority), ani (the injustice of oppression), and anawim (a political movement of the pious poor).1

The word used for poor in Deut $15: 4,7,11$ is ebyon. The only other place in the Pentateuch that ebyon is used is Exod 23:3, 6, 11. The context in which the word is used in Exod 23 does not help us define its meaning (Exod 23:3, "and do not show favoritism to a poor man in his lawsuit").

outside of the Pentateuch ebyon is frequently used in the book of Job. "He saves the needy from the sword in their mouth; he saves them from the clutches of the powerful" (Job 5:15). "I was a father to the needy" (Job 29:16). From these and other uses of ebyon in Job, we understand the word as referring to the weak and the needy. Ebyon is also used frequently in the Psalms. In Ps 112:9, "He scattered abroad his gifts to the poor," and in Ps 132:15, "I will bless her with abundant provision, her poor will I satisfy with food." From the use of the word in the context of the Psalms, it seems to refer to those who are in need of food and other material things.

\footnotetext{
'David Noel Freedman, "Poor," The Anchor Bible Dictionary (New York: Doubleday, 1992), 402-403.
} 
Returning to the Pentateuch, we find that Deut 24:14 helps us further clarify the meaning of ebyon. "Do not take advantage of a hired man who is poor and needy, whether he is a brother Israelite or an alien living in any of your towns." This seems to suggest that ebyon includes landless poor.

Based on the use of ebyon in the Pentateuch, Psalms, and Job, we will use the following definition when referring to the poor (ebyon): those who are in need of food and material possessions, the landless.

The clarification of another word which should help in the understanding of the passage is "release." The basic meaning of shamat is "to put down." Shemittah is the remission of debt of suspension of labor. It means "release."

These words shamit and shemittah are used in a unique sense in Deuteronomy. "At the end of every seven years you must cancel debts" (Deut 15:1). Vs. 2 describes how the debts should be cancelled. Lenders should not require payment of debts from other Israelites because YHWH's time for putting down debts or release has come. It was time to cancel debts.

"You may require payment from foreigners but you must cancel any debt your brother owes you." Vs. 3 clarifies how the "release" should be implemented. 
Deut 15:9 (NIV) states, "Be careful not to harbor this wicked thought, "The seventh year, the year for canceling debts, is near' so that you do not show ill will toward your needy brother." The text appears to set further guidelines for the implementation of the release. It also includes what will come if the release is not granted.

From the use of shemittah and shamat in Deuteronomy, a reasonable conclusion is that the time of release was when the poor should be released from their debts. Lenders should continue to make loans even when the time for canceling debts was near.

Deut 31:10 sets a time within the seventh year when the release should be implemented: "At the end of every year, in the year for canceling debts, during the Feast of Tabernacles."

A clarification of the meaning of "neighbor" and "brother" should further help in the understanding of the passage. "He shall not exact of his neighbor or of his brother because one has proclaimed the release of YHWH" (Deut 15:1-11).

The basic idea for neighbor (rea) is inclusive. It could include brother, companion, or friend. The basic idea for brother ( $\underline{\mathrm{akh}}$ ) would be blood relationships. It does seem that both words are used to convey the idea that all permanent residents and nationals who are blood related should be released from their loans at the time of release. 
Background of the Passage

Moses was coming to the end of his life and

leadership. He had been told by God that he would not lead the people over Jordan. Before Israel crossed Jordan, Moses addressed them. He reminded them of God's care over them in the past. He assured them that God would continue to lead them in the future. He reminded them of their social responsibilities and of the blessings and curses which would come if they did not obey all the commandments of the Lord. Deut 15:1-11 is part of Moses' second speech which begins in Deut 4:22. The main emphasis of these verses is to remind Israel about their social responsibilities to the poor. The text also reminds Israel about the blessings that will come if they obey the command to show concern for the poor, and the curses which will come if they do not heed the command.

\section{Blessings and curses were part of Near Eastern}

treaties. For example, we find blessings and curses in a treaty between the Egyptians and the Hittites.

As for the words which are on this tablet of silver of the land of Hittite and the land of Egypt as for him. who shall not keep them a thousand gods of the land of Hittite, together with a thousand gods of the land of Egypt, shall destroy his house, his land and his servants. But as for him who shall keep these words which are in these tablets of silver, whether they are Hittite or whether they are Egyptian, and they are not neglectful of them, a thousand gods of the land of Egypt, shall cause that he be well, shall cause that he 
live, together with his houses and with his lands and his servant."

While they are not explicitly stated, several suggestions of blessings and curses can be seen in the passage. In Deut 15:4, 5 the blessing is based on obeying the command. This implies that failure to obey the command will result in a curse. The appeal to the Lord in vs. 9 seems to result in a curse.

Exodus and Leviticus provide the main biblical background for Deut 15. Exod 23 expresses concern for the poor and the release of the seventh year.

Do not oppress an alien, you yourself know how it feels to be aliens because you were aliens in Egypt. For six years you are to sow your fields and harvest the crops, but during the seventh year let the land lie unplowed and unused. Then the poor among your people may get food from it, and the wild animals may eat what they leave. Do the same with your vineyards and your olive groves. (Exod 23:9-11)

Lev 25:1-11 broadens the scope of the release to include temporary residents, hired workers, and manservants.

The Lord said to Moses on Mount Sinai, "Speak to the Israelites and say to them 'When you enter the land I am going to give you, the land itself must observe a Sabbath to the Lord. For six years sow your fields and for six years prune your vineyards and gather their crops. But in the seventh year the land is to have a. Sabbath rest. . . . Whatever the land yield during the Sabbath year will be food for yourself, your manservant, and the hired worker and temporary resident who live among you'." (Lev 25:1-7)

While Deut 15:11 reflects the social and ethical directives given in Exod 23:9-11 and Lev 25:1-7, this is not

'James Pritchard, ed., Ancient Near Eastern Texts (Princeton, NJ: Princeton University Press, 1950), 201. 
a mere repetition of these passages. The writer uses these concepts from Exodus and Leviticus to present a new aspect of release. He links the time of release with the release of the poor from debts.

Having considered the background to the passage we now analyze the text.

\section{Analysis of the Text}

The sections of Deut 15 analyzed are: "There will be no poor among you for YHWH will bless you in the land which YHWH your God will give you for an inheritance" (vs. 4); "If there is among you a poor man of your brethren in the land of which YHWH your God will give you" (vs. 7); and "The poor will never cease out of the land" (vs. 11).

In an attempt to seek to resolve the apparent contradiction, "There will be no poor among you" and "The poor will never cease out of the land," which these verses pose, they must be placed within the context of the passage.

Vs. 4 suggests that something vital went before. Vss. 1-3 set out the law for the time of release. Vs. 1 defines the time of release, "every seventh year." It does not make any room for escape from the release law because the command of God is stated in the imperative, "You shall grant release."

Vs. 2 expands on the nature of the release by describing how the cancellation should be implemented. The 
release should include everyone who had a loan, whether blood relation or resident aliens.

A summary of vss. 1-3 indicates three things. First, there is a time for the release. Second, it describes the nature of the release. Third, it tells us that the command to release is a divine imperative because it is YHWH's release.

Having looked at vss. 1-3, we move on to vs. 4 : "However, there will be no poor among you for YHWH will bless you in the land which YHWH your God will give you for an inheritance." In the context of the writer's reminder to the people to implement the release law when they entered the land, one might conclude that the reminder and the subsequent expansion to include the release of the poor were to ensure that there would be no poor in the land.

Vs. 5 may be important in helping us to understand the passage: "If only you will obey the voice of YHWH your God, being careful to do this commandment which I have commanded you to do." If this should be looked at as a conditional sentence, one possible reading of the text could be, "If you do this, the Lord will bless you so that there will be no poor in the land." If the command to release the poor and needy were observed, there would be no poor in the land. The text can be translated, "Should there be any poor in the land." 
If vs. 7 expresses the possibility that there might be poor in the land, vs. 11 states that "the poor will never cease out of the land, therefore I command you . . open wide your hands."

While the possibility of having poor in the land that YHWH gives appears to be a contradiction, YHWH is associated with abundance and blessings. YHWH made provision that should the unexpected happen, should there be any poor in the land, their needs should be met.

Vs. 11, "For the poor will never cease out of the land," seems to imply a prediction which must come to pass. The poor would be in the land if the community failed in its responsibilities.

This sermon is a summons to meet the poor at all times with open hands. The preacher has realistic ideas about poverty. He knows that Israel will always have to deal with it. This conception seems to have provided a contrary opinion, namely, that complete obedience will be assured by complete divine blessing and hence the end of poverty.1

The passage's main thrust is not to suggest that there would be no needy person in the community. The passage seems to make provision for the needy in the community. Should the community exercise compassion, all needs could be met.

One of the issues that vs. 11 raises is the statement, "The poor will never cease from the land." This

\footnotetext{
${ }^{1}$ Gerhard von Rad, Deuteronomy: A Commentary (London: SCM Press, 1988), 106.
} 
statement could have been describing the current condition in the Israelite society or it could have been predicting that there would always be poor in the community.

The context of Deut 15 is not dealing with a divine institution of poverty. The passage is about God's concern for the poor and needy and His appeal to the community to share this concern.

\section{Interpretation of the Text}

The speech was clear in terms of its limitation. The Release Law should include Israelites and resident aliens. The time for release was clearly stated--it should be the seventh year.

From what Deut 15:9 says, there might have been a problem about making loans when the time of release was near. One can understand the problem that the lender might face if during the sixth year someone needed a loan, because the loan would have to be cancelled within months.

Those who heard the speech must have been aware that the Release Law, which affected the lives of the poor, was God's way of providing for the needy. Should the Israelites live up to their social responsibilities by sharing with the needy, they would be blessed. But should they fail, the poor would "appeal to the Lord."

It is vital that the modern reader understand that "poor" in the passage is not referring to those who are oppressed, unjustly treated, or those who are lazy. The 
poor (ebyon) are mainly the landless who have fallen into financial and material need.

The Law of Release was instituted by God to provide for the needy. The conciliation of debts, the returning of the land, and the permanent availability of loans would ensure that there would be no poor in the land because their needs would be provided.

This ideal condition of not having poor in the land could only be realized if the community followed God's laws in general and specifically the Law of Release. The blessing which would result from obeying these laws would guarantee that there would be no poor in the land.

"The poor will always be in the land" should not be taken to mean that some individuals have been condemned to live in poverty. The statement is describing only what would occur when the community failed to provide for the needy .

There are poor and there will be poor, not because some have been predestined to live in poverty. The reason why there are poor in the community is because the community has not lived up to its responsibilities. Even an omnipotent God chooses to work through humans. One of the vital issues that the modern reader should understand about this passage is that it was addressed to an agricultural society. The practical nature of implementing the release system in a modern economy with 
stocks and shareholders may seem impossible. However, the principle of those who have been sharing with the weak is something that society should not ignore.

The community should note that this passage shows God's concern for the weak. While it did not work in the Israelite community, the Christian community should strive to meet this ideal.

\section{Matt $25: 31-46$}

Matt 25:31-46 is part of Jesus' final address to His disciples. This address begins in chap. 24 and was given in response to the disciples' question, "Tell us . . when will this happen, and what will be the sign of your coming and of the end of the age?" (24:3).

Two parables precede the passage. The parable of the ten bridesmaids centers on the theme of being ready because no one knows when the bridegroom will come (24:113). The parable of the faithful servant addresses the issue of rewards and condemnations; the faithful are rewarded and the unfaithful are condemned (24:14-30).

While there is some implied parabolic language within Matt 25:31-46 (for example, the reference to "sheep and goats"), the passage does not seem to fall into the category of parables. Rather, its central motif is the end of the world. All nations will come before the king for judgment. 
Analysis of the Passage

We now seek to find out the meaning of the passage. How might those who heard it first have understood it? How should the modern reader understand the passage? There are vital issues that will need clarification if one is going to understand the passage. Among these issues are: What is the significance of the national gathering before the son of Man? What are the criteria that the judge uses to divide the nations? Who is referred to as brethren?

Son of Man

The phrase "Son of Man" seems to express eschatological language. Other passages in Matthew use the phrase "Son of Man" in an eschatological judgment context. "For the Son of Man shall come in the glory of His Father with His angels; and then He shall reward every man according to his works" (Matt 16:27). "And Jesus said unto them, Verily I say unto you, that ye which have followed me, in the regeneration when the son of man shall sit in the throne of his glory, ye also shall sit upon twelve thrones, judging the twelve tribes of Israel" (Matt 19:28) . "And then shall appear the sign of the Son of Man in heaven" (Matt 24:30).

The phrase "Son of Man" is also used outside of Matthew. One significant use is found in the eschatological section of Daniel. 
I saw in the night vision, and, behold, one like the Son of man came with the clouds of heaven, and came to the Ancient of days, and brought him near to him. And there was given to him dominion, and glory, and a kingdom, that all people, nations, and languages, should serve him: his dominion is an everlasting dominion, which shall not pass away, and his kingdom which shall not be destroyed. (Dan 7:13, 14)

The context in which the Son of Man is used in these two verses suggests that it relates to judgment. The son of Man is described as the one who receives dominion after judgment has been handed down.

Based on how the phrase "Son of Man" is used in Matthew generally, and in Dan 7 and the immediate context of Matt 25:31-33, one can conclude that the "Son of Man" refers to the eschatological coming at the end of the age.

The context of the question which brought about this response, "Tell us when these things will be? and what shall be the sign of thy coming, and of the end of the world?" (Matt 24:3), suggests that the disciples understood that Jesus was referring to His coming to judge at the end of the age.

The passage also outlines the standard that the judge will use to divide those who will be rewarded from those who will be condemned. The standard of judgments is plainly described as caring for those who are in need. People will be judged based on their attitude to those who are hungry, thirsty, strangers, and in prison. It is significant that the judge identifies with each human need by stating that when these needs are met, His needs are 
met, and when these needs are not met, His needs are not met.

The Brethren

A crucial part of the passage under consideration which is vital for understanding the context is, "Who are the Brethren?" The Son of Man says: "Just as you did it to the least of these my brethren."

A review of the history of interpretation on Matt 25:40 shows that there have been three main ways of interpretation: (1) the restricted interpretation, where "brothers" refers to the disciples or followers of christ; (2) the neutral interpretation, where commentators do not comment on the text; and (3) the universal interpretation, where "brothers" refers to all those who are in need.

The first and third interpretations appear in Ireneaus and Paul the Deacon. "Ireneaus of Lyons (A.D. 130203) was the first church father to use this quotation from Matthew and relate it to christ identifying himself with the poor. He suggests that when we give our fellow humankind we give to God."1 on the other hand, Paul the Deacon (ca. A.D. 720-80) suggests that while it is possible to give a universal interpretation to Matt 25:40, a more valid

${ }^{1}$ Sherman W. Gray, The Least of These My Brothers: Matthew 25:31-46, A History of Interpretation (Atlanta: Society of Biblical Literature, 1986), 13. 
interpretation would be restricted to brothers as Christians who live in poverty. ${ }^{1}$

Sherman w. Gray, in his well-documented

dissertation, states that there is a significant increase in the universal position with regard to "the least" in the twentieth century. On the one hand, he argues that 53 percent of authors argue for a universal position; however, this 53 percent includes the 19 percent who remained neutral by not commenting. On the other hand, he rightly suggests that if the 19 percent of the neutral are taken into consideration, the restrictive position would be the major position taken by commentators in the twentieth century. ${ }^{2}$

To further clarify the meaning of "brethren," we now turn to the use of "brethren" in other passages of Matthew: Matt $12: 48-50 ; 18: 15,21,35 ; 32: 8 ;$ and $28: 10$.

Two significant words in the New Testament explain the meaning of "brother." Adelphos--whose basic meaning describes those who come from the same womb, thus describing blood brothers and sisters--was later expanded to include all near relatives. The second word plēsios includes neighbor and resident aliens as brothers. ${ }^{3}$

But he answered and said unto him that told him, who is my mother? and who are my brethren? And he stretched
${ }^{1}$ Ibid., 151 .
${ }^{2}$ Ibid., 348 .
${ }^{3}$ Colin Brown, Dictionary of New Testament Theology (1975), s.v. "Brother." 
forth his hand toward his disciples, and said, Behold my mother and brethren. For whosoever shall do the will of my Father which is in heaven, the same is my brother, and sister, and mother. (Matt 12:48-50)

The context of the text above suggests that Jesus was not using "brothers" to refer to His siblings. Jesus was using "brothers" in a wider sense to refer to those who do the Father's will. This use of the word "brothers" appears to support the universal understanding of brethren.

Moreover if thy brother shall trespass against thee, go and tell him his fault between thee and him alone; if he shall hear thee thou has gained thy brother. Then came Peter and him, and said, Lord, how oft shall my brother sin against me, and I forgive him? Till seven times? So likewise shall My heavenly Father do also unto you, if you from your hearts forgive not every one who his brother trespasses. (Matt 18:15, 21, 35)

The passage above seems to relate the word "brother" to the Christian community. The context in which this passage is set points to the Christian's relationship with his fellow Christians. In this context "brother" does not point to the Christian relating to those who are not Christians.

"But be not ye called Rabbi: for one is your Master, even Christ; and all ye are brethren" (Matt 23:8). "Brethren" in this context is referring to the disciples as belonging to one family. We can conclude that brethren is used in terms of the believing community.

"Then said Jesus unto them, be not afraid: go tell my brethren that they go into Galilee, and there shall they 
see me" (Matt 28:10). This text refers to the Christian community.

There is another context in which "brethren" is used in Matthew's Gospel:

But I say unto you, that whosoever is angry with his brother without a cause shall be in danger of the judgment: and whosoever shall say to his brother, 'Raca,' shall be in danger of the council: but whosoever shall say, 'Thou fool' shall be in danger of hell fire. (Matt 5:22)

The context of the passage suggests that ethical behavior should not be limited to those within the community of faith, but that it should be extended to any human being. There are other uses of "brother" which also fall into this general category, such as Matt 7:3-5.

The use of the word "brother" has been used in more than one context within the book of Matthew. In the first, "brother" refers to those within the Christian community; in the second, "brother" refers to any human being. The question remaining regards the meaning of "brothers" in Matt 25:40. Based on evidence from the history of interpretation and the context in which the term "brethren" is used in Matthew, we may conclude that "brethren" should be understood in the restricted sense. "Brethren" refers to those within the Christian community who are followers of Christ.

If we read Matt 25:40 with the understanding that "the least of these my brethren" is restricted to those within the Christian community, we would have to dismiss 
some previously held presuppositions. Among these is the assumption that "brethren" refers to all those who are in need, consequently promoting an exclusive ethical practice, which would eliminate any justification and claims of Christianity as an inclusive religion, while the passage seems to promote an exclusive ethical practice.

The Seventh-day Adventist Bible Commentary seems to be aware of the dilemma in which a restrictive reading of Matt 25:40 has on the scope of Christian ethical teaching. on the one hand, it argues that "brethren" refers to Christ's chosen ones, where Christ is said to identify with the suffering of His followers. On the other hand, it suggests that the principle which is involved in Matt 25:40 is illustrated in the parable of the Good Samaritan in luke 10:25-37.1 It would have been interesting if the seventhday Adventist Bible Commentary had stated what the text means, because the evidence for a restrictive reading of the text is impressive.

Does a restrictive reading of Matt 25:40 detract from the inclusive ethical teaching of Jesus? I do not think so. It seems to me that two relevant issues may clarify the situation. The first is, How did the first hearers and readers understand the passage? From the internal evidence, it would seem that those who first heard

1 "Matthew" and "Luke," SDABC, ed. Francis D. Nichol (Washington, DC: Review and Herald Publishing Association, 1980), 5:512. 
the speech and those who read it afterwards understood it in its restrictive sense. The second issue is, How should the text be understood in a modern society? Every generation should read the text in the context of its contemporary society.

A modern re-reading of the text would lead to the reinterpretation of Matt 25:40, thus removing the text from a restrictive understanding and placing it within the broader, more inclusive understanding. With an inclusive understanding, the reader would then not limit "brethren" only to the christian community, but would think of "brethren" in the wider concept of the Fatherhood of God and the brotherhood of mankind.

Another more traditional position which could influence an understanding of the passage is the idea that all truth should be studied within the context of the whole body of truth. While there is evidence in scripture of a bias to meeting the needs of the Jewish and later the Christian community, there is also evidence that Jesus had a caring ministry which included all people. The account of the good Samaritan is one of many examples.

Jesus did not limit His liberating ministry (Luke $4: 18$, 19) to the Christian community. It does not seem that Jesus' ministry to the needs of humankind was limited to any community. He came to bring liberation to all those who were in need. 
A reading of Matt 25:31-46 suggests that there are universal themes and that there are also restrictive themes. For example, the gathering of the nations before the son of man is a universal theme. The "brethren" (25:40) is restricted to those within the christian community. Yet when Matt 25:31-46 is looked at within the context of Jesus' inclusive ministry and in the context of the whole body of Scripture it becomes a guide for how we should treat all those who are in need. It does not seem to be compatible with the practice of Jesus to limit a caring ministry only to those within the Christian community. Jesus' practice in ministry showed concern to meet the needs of all those who are hungry, thirsty, and naked.

\section{Luke $4: 17-20$}

Luke places Jesus reading the Scripture in the synagogue on the sabbath shortly after His baptism, when Jesus was anointed by the Holy spirit. Luke 4:17-20 is not only important for the caring themes that it presents, but because of the historical background from which it comes. The background of this passage comes from the old Testament texts Isa $62: 1,2$ and Isa 58:6. The context of these background texts should help in establishing the meaning of Luke 4:17-20. One important issue which needs clarification is whether this passage is addressing literal liberation or spiritual liberation. 
The Spirit of the Lord God is upon me, because the Lord hath anointed me to preach good tidings unto the meek, he hath sent me to bind up the brokenhearted, to proclaim liberty to the captives, and the opening of the prison to them that are bound; to proclaim the acceptable year of the Lord, and the day of vengeance of God; to comfort all that mourn. (Isa 61:1, 2)

Isaiah 61:1, 2 has a Jubilee motif. "To proclaim the acceptable year of the Lord" is referring to the year of release which is part of the Jubilee. If the Jubilee year was a time when debts were released and land was returned to the owner, why should the text be spiritualized when it is quoted by Jesus in Luke $4: 16-20 ?$

The Seventh-day Adventist Bible Commentary has taken a balanced approach. On the one hand, it argues that the poor in Luke 4:16-20 were people experiencing genuine hardship, which at times was caused by oppression from the wealthy. On the other hand, it also suggests that it might be possible that Jesus was referring to the poor in spirit. ${ }^{1}$

It does seem that interpreters who take a balanced approach to the interpretation of Luke 4:16-20 tend to come to a better understanding of the passage. However, the general tendency has been to emphasize the spiritual at the expense of the literal, or to emphasize the literal and ignore the spiritual.

Before proceeding with the analysis of the passage, we need to note that Isa $58: 6$ is also part of its background. "Is not this the fast that I have chosen? to

1"Luke," SDABC, 5:728. 
loose the bands of wickedness, to undo the heavy burdens, and to let the oppressed go free, and that ye break every yoke." While the context of Isa 58:6 could be interpreted in a spiritual context because humankind is always in need of release from the burden of $\sin$ and the yoke of transgression, its context is dealing with the need for spiritual reformation that will result in the literal breaking the yoke of the oppressed so that they can be liberated.

John Nolland points out that Isa 58:6 makes a significant contribution to Luke $4: 16-20$ by stating that the time of salvation comes with the announcement. ${ }^{1}$

The Spirit of the Lord is upon me, because he hath anointed me to preach the gospel to the poor; he hath sent me to heal the brokenhearted, to preach deliverance to the captives, and recovering of sight to the blind, to set at liberty them that are bruised, To preach the acceptable year of the Lord. (Luke $4: 18,19$ )

Anointing is the basis of Jesus' authority to proclaim the word. Luke $4: 18,19$ cannot be confined to the reading of scripture because the passage also contains proclamation and interpretation. There are those who suggest that the anointing relates to Jesus' baptism when the Holy Spirit came upon Him. ${ }^{2}$ The passage also implies

${ }^{1}$ John Nolland, Luke, Word Bible Commentary (Dallas: Word Books, 1982), 196.

${ }^{2}$ Alfred Plummer, The Book of Luke, International Critical Commentary (Edinburgh: T. \& T. Clark, 1995), 121. 
that Jesus was anointed (empowered) to perform specific tasks.

One of the tasks for which Jesus was empowered or sent with authority was the preaching of the gospel to the poor. There is debate as to the meaning of "poor" in the passage. Some argue that "poor" refers to the "poor in spirit" (Matt 5:3). Some Third World theologians do not share this view; among them is Gustavo Gutierrez who states that "poor" in this passage refers to the economic poor. Plummer suggests that "poor" in Luke 4:16 conveys the idea of abject poverty.

The context of Luke $4: 18$ and the historical background from which it comes seem to imply that the poor is referring to the economically poor who were in need of deliverance. It does not seem possible to bring spiritual liberation while ignoring the needs of the economic poor. If we should assume that the proclamation in Luke 4:16-20 was made at the beginning of Christ's ministry, then the practical example of Christ's ministry is an example of how the needs of the poor and hungry can be met. There are many examples of Christ providing for the physical needs before the spiritual.

Commenting on the meaning of "poor" in Luke 4:18, John Nolland argues that Luke does not portray Christ as a social reformer. Luke, according to Nolland, does not depict Christ as being involved in the political structure 
of his time. However, Luke describes a Christ who is deeply concerned with the literal, physical needs of humankind and with their spiritual needs. ${ }^{1}$

A second area of Christ's liberating ministry was "to heal the brokenhearted." The Seventh-day Adventist Bible Commentary is consistent with its major emphasis on the spiritual interpretation of luke 4:18. While recognizing that "brokenhearted" could describe those who have been disappointed because of adverse circumstances, it concludes that the main emphasis is on those who have broken hearts because of their sense of sinfulness.

While not ignoring the position taken by The Seventh-day Adventist Bible Commentary, there seems to be other ways that "brokenhearted" can be understood. It is possible the individuals could become brokenhearted because of the rigors of an oppressive system. The historical context of the passage seems to point to individuals who have been broken by an uncaring system.

The last section of this verse seems to be set in liberating language: "to preach deliverance to the captive," "recovering of sight to the blind," "to set at liberty them that are bruised." But we cannot only interpret the passage as physical or spiritual liberation because there are several ways of looking at the text. For example, Alfred Plummer suggests that another way of looking

${ }^{1}$ Nolland, 197. 
at the text is to attribute deliverance from captivity and the restoring of the sight to the blind to "captives in exile, some of whom had been blinded by their captor, or by long confinement in the dungeon."1

The New Jerome Bible Commentary suggests that the passage should be looked at in the context of the year of Jubilee. With the Jubilee concept in mind, those who are to be released from prison are those who are in prison because they are not able to pay their debts. ${ }^{2}$ Given the old Testament background of this text (Isa 62:1, 2; 58:6), the Jubilee motif should not be ignored when considering the meaning of the last part of Luke $4: 18$.

\section{The Seventh-day Adventist Bible Commentary argues} that "the captives" are not given physical freedom; rather the passage is alluding to the need to be freed from Satan's captivity. The blind are not literally blind, but spiritually blind. While admitting that scripture speaks about letting the oppressed go free, it suggests that the bruised to be freed is relating to spiritual freedom. ${ }^{3}$

Another way of looking at the last part of Luke 4:18 is to consider how Jesus' ministry exemplifies these characteristics. For example, when John sent his disciples

${ }^{1}$ Plummer, 121 .

${ }^{2}$ The New Jerome Biblical Commentary, ed. Raymond E. Brown and Joseph A. Fitzmyer (London: Prentice, 1990), 610.

"Luke," SDABC, 728 . 
to ask Jesus if He was the Christ, Jesus' response was, "Go back and report what you have seen and heard. The blind receive their sight, the lame walk, those who have leprosy are cured."

Jesus' ministry provides many examples of blind individuals who received their sight. There are also examples of individuals who were liberated from sickness. Jesus demonstrated compassion in feeding people who were hungry.

One of the most important contributions that Jesus made in His proclamation in Luke 4:16 was the declaration that "the acceptable year of the Lord has come." This was clearly referring to the Jubilee year when people would be liberated from debt and the land would be returned to its owner. It does seem that Jesus was speaking about physical liberation as well as spiritual liberation.

\section{Conclusion}

The four passages which we have observed suggest that God is concerned about the poor. For example, the Exodus narrative shows God is concerned for those who are oppressed. Deut 15:1-11 shows God's concern for the poor within the Israeli community. Matt 25:31-46 teaches that individuals will be judged based on how they respond to the needs of others. Luke 4:17-20 sets Jesus' ministry within the context of the Jubilee, which was a time of liberation from debts. There is evidence in these passages for a 
ministry to those who are in need. 
CHAPTER 4

ELLEN WHITE'S CONCERN FOR THE POOR

There are many reasons why Ellen G. White's writings are a good source for exploring the subject of poverty. The length of her publishing ministry spans over sixty years (1851-1915). During this time she wrote 100,000 manuscripts, published 5,000 articles, and wrote twenty-six books. Her ministry was international in nature. From 1885-1887 she visited England, France, Italy, Denmark, Norway, Sweden, and Germany. From 1891-1900 she lived in Australia. E. G. White did not confine her writings to poverty in the United States of America. She wrote about poverty in England, France, and Australia.

One of the significant aspects of E. G. White's contribution to the subject of poverty is the personal and practical way she dealt with the poor. She had a personal concern for the poor which was demonstrated by the way she sought to help them. Her example and suggestions that she made on how to relate to poverty provide guidelines for society and the church. 


\section{Personal Traits of Character}

Ellen White lists several character traits that cause poverty.

1. The failure to practice good economic principles contributes to poverty.

Many are poor from their own lack of diligence; they know not how to use means aright. . . . Some will always be poor. If they should have the very best advantages their cases would not be helped. They have not good calculations, and would use all the means they obtain, were it much or little. ${ }^{1}$

2. Idleness has brought many to poverty. Ellen

White suggests that it has prevented "thousands from rising out of degradation and wretchedness." "2

3. Waste is another factor, in Ellen White's opinion, which contributes to poverty. About the poor she says: "They do not know how to manage. Often through lack of carefulness and right judgment there is wasted that which would maintain their families in decency and comfort." 3

4. Improper use of time contributes to poverty. She advised that the poor should get up early and work diligently. "By learning to waste no time" they could improve their lot. ${ }^{4}$

${ }^{1}$ Ellen G. White, Testimonies for the Church, 9 vols.
(Boise, ID: Pacific Press, 1985) $1: 272$.

${ }^{2}$ Ellen G. White, The Ministry of Healing (Mountain View, CA: Pacific Press, 1905), 197.

${ }^{3}$ Ibid., 195 .

${ }^{4}$ Ellen G. White, Welfare Ministry (Washington, DC: Review and Herald, 1952), 198. 
5. Personal sins are also a cause for poverty. Commenting on this she says that "the poor should first understand that their sickness and poverty are misfortunes most generally caused by their own sins, follies, and wrongs." 1

6. Lack of diligence is another significant factor that contributes to poverty. Ellen White states that the reason why many are poor is because of their own "lack of diligence and economy."2

Ellen White states that personal character traits are the main reason for poverty. From this we may conclude that it is possible for the poor to break out of the poverty trap by improving their characters.

\section{External Factors Which Cause Poverty}

Ellen White does not accept that the causes of poverty are not limited to personal reasons. She points to external factors which may bring about or cause poverty. These may include:

1. "Dishonest scheming by others, misfortune, sickness and loss of property." ${ }^{3}$

${ }^{1}$ White, Testimonies, 1:642.

${ }^{2}$ Ibid., 272.

${ }^{3}$ White, Welfare Ministry, 276. 
2. The significant contribution that Ellen White makes is suggesting that a reason for poverty is the abandoning of God's plan.

In God's plan for Israel every family had a home on the land with sufficient ground for tilling, thus were provided both the means and the incentive for a useful, industrious, and self-supporting life. And no devising of men has ever improved upon this plan. To the world's departure from it is owning, to a large extent, the poverty and wretchedness that exist today.1

with this statement Ellen White's arguments on poverty can be seen in balance. On the one hand, there are personal reasons why people fall into poverty. On the other hand, there are external reasons why individuals fall into poverty.

Ellen White did not explicitly address one of the contemporary causes of poverty--the role that oppressive government contributes to the creation of poverty. It is almost impossible for some societies to break out of the poverty trap because of the oppression that they experience.

\section{What Should Be our Attitude to the Poor?}

Ellen White had a great burden for the poor. The counsel that she gave covers various aspects on how to relate to the poor. She suggested that when one has a relationship with Christ, one will be concerned about the poor.

All who are living in daily communion with Christ will place his estimate upon men. They will reverence the

${ }^{1}$ White, The Ministry of Healing, 183. 
good and the pure, although these are poor in this world's goods. James says, "My brethren, have not the Lord Jesus Christ, the Lord of glory, with respect of person. For if there come unto your assembly a man with a gold ring, in goodly apparel, and there come in also a poor man in vile raiment; and ye have respect to him that weareth the gay clothing, and say unto him, sit here . . Hath not God chosen the poor of this world rich in faith and heirs of the kingdom? . . But you have despised the poor. ${ }^{1}$

Writing in the Advent Review and Sabbath Herald, she stated that what God desires is mercy, tenderness, and compassion. She suggested that when tenderness and compassion are practiced, fraud and oppression will end. "All authority, will, and influence will be used to help the poor and the oppressed."

While it is beyond doubt that Ellen White sided with the poor, she was not fanatical in her counsel on how to deal with the poor. Rather, she adopted a rational approach. She was prepared to look on the merit of each case. For example, she categorized the poor into "deserving poor": those who should be helped, and those who should not be helped. She did not advocate wholesale assistance to the poor.

While we should show sympathy and love for the deserving poor we are not to favor the unworthy poor because they are poor, neither are we to honor "the person of might," simply because they are mighty. How much of this is done? If a man is possessed of wealth, great respect, applause and honor are given to him

\footnotetext{
${ }^{1}$ Ellen G. White, "First-Day offerings and the Foreign Missionary Work," Advent Review and Sabbath Herald, October 6, 1891, 609 .
} 
because of his position, while he may be corrupt at heart, and his life unworthy of imitating. ${ }^{1}$

\section{Who Are the "Deserving Poor"?}

Among the "deserving poor" are the orphans, widows, strangers, sick, and those who have become poor because of misfortune. Those who are poor because of indolence and because they refuse to work should not be helped.

There are few in our land of plenty who are really so poor as to need help. If they would pursue a right cause they could in almost every case be above wants. . . The worthy poor, those who are made poor by misfortune and sickness, deserve special care and help. ${ }^{2}$

From Ellen White's teaching on how to relate to the poor, it seems that she argues that the poor should show signs of responsibility. The poor are expected to work, the poor are expected to contribute to the church by bringing their offerings. Poverty was not an excuse for avoiding one's responsibility to others or to God.

In the balance of the sanctuary the gift of the poor, made from love to Christ, are not estimated according to the amount given, but according to the love which prompts the sacrifice. The promise of the poor man who has but little to offer, but who gives that little as freely as by the wealthy man who gives of his abundance - . There is a sacredness in the poor man's offering. that is not found in the rich man's gift. ${ }^{3}$

\footnotetext{
the Times, July $22,1880,6$.

${ }^{2}$ White, Welfare Ministry, 202.

${ }^{3}$ White, Testimonies, $4: 509$.
}

${ }^{1}$ Ellen G. White, "Special Requirements," Signs of 
The obligation to relate to and show concern for the poor is a significant part of Ellen White's social teaching. When we reflect that she wrote during the nineteenth and early twentieth century, it is significant that she dealt with such issues as oppression, misfortune, and sickness as causes of poverty for which the individual did not have any responsibility.

\section{The Church and the Poor}

Ellen White set out what should be the attitude of the church toward the poor while dealing with a specific situation in Battle creek. However, the principle can be applied generally to all churches.

It is the duty of every church to feel an interest for its own poor. But many selfish ones have felt gratified to have their poor members move to Battle Creek, for then they would not be required to help support them. The Battle creek church spends every year from one to five hundred dollars for the support of the poor and sick, whose families must suffer for the necessities of life; therefore there is a continual draft upon the funds of those at the heart of work. ${ }^{1}$

She appeals to members that they should show their concern for the poor by practicing self-control in their personal spending. They should think about the poor before they engage in unnecessary spending.

Deny yourselves of something in your houses or in your dress, and lay by a sum for the needy poor. Let not your tithes and thank offerings to God be less, but let it be in addition. God does not propose to rain means from heaven to sustain the poor, but He has placed His

${ }^{1}$ Ibid. 
goods in the hands of His agents. They are to recognize christ in the person of His saints and what they do for His suffering children they do for Him, for He identifies His interest with that of suffering humanity. By denying yourselves and lifting the cross for Jesus, who for your sakes became poor, you can do much toward relieving the suffering of the poor among us, and by thus imitating the example of your Lord and Master you will receive His approval and blessing. ${ }^{1}$

In 1893, she reminded the church of its responsibilities to provide funds for the preaching of the Gospel and "to care for the poor as representatives of Christ." The members should provide additional funds other than their tithes to care for the needs of the poor. God might have carried forward $\mathrm{His}$ work in the world, and provided for the poor without the cooperation of man. He has given us this opportunity so that we may demonstrate love for others and in doing this we will receive spiritual strength. ${ }^{2}$

Some preliminary conclusions seem to be emerging. One reason why the church should take care of its poor is because Christ identified with the poor. In showing concern for the poor the church is standing in place of christ. Those who minister to the needs of the poor derive spiritual blessings.

In The Signs of the Times, Ellen white wrote that no church should feel itself above the poor. The church should not cultivate an atmosphere that the poor will feel unwelcomed. "As long as there are hungry ones in God's world to be fed, naked ones to be clothed, souls perishing

\footnotetext{
${ }^{1}$ Ibid. , 511.

${ }^{2}$ Ibid.
} 
for the bread and water of salvation . . every unnecessary indulgence pleads for the poor and the naked."1

The scope of Ellen White's advice and how the church should deal with its poor includes specific advice on who should be invited to the Thanksgiving meal. She questioned how many would follow the instruction of christ on Thanksgiving Day: "When thou makest a feast, call the poor, the maimed, the lame, the blind, and thou shall be blessed" (Luke 14:13). She suggested that the poor, the widow, and the fatherless should be invited to the Thanksgiving meal. She also stated "Then let us keep Thanksgiving God's own way, and no longer follow the custom of the world, selfishly heaping our favors upon a few favorites and neglecting those who profess to be children of God."2

While the evidence from Ellen White's counsel on how the church should deal with its poor is weighted in favor of each church taking care of its poor, at times she advised against the practice of meeting the need of some poor who have joined the church.

God does not require our brethren to take charge of every poor family that shall embrace this message. If they should do this, the work of the messenger to enter new fields must cease, for the fund would be exhausted. Many are poor from their own lack of diligence and economy. They know not how to use means aright. If they should be helped it would hurt them. Some will

\footnotetext{
'Ellen G. White, "Blessed Is He That Considereth the Poor," Signs of the Times, June 20, 1892, 495.

${ }^{2}$ Ellen G. White, "The Coming Thanksgiving," second Advent Review and Sabbath Herald, November 18, 1884, 729 .
} 
always be poor. If they should have the very best advantages, their case would not be helped. . . If the church should help such individuals instead of leaving them to rely upon their resources, they would injure them in the end, for they took to the church, and expect to receive help from them, and do not practice self-denial.

A summary of Ellen White's counsel on how the church should relate to its poor reveals that each church should take care of its own poor. The church should particularly be concerned about the "worthy poor," those who have become poor because of misfortune and sickness. The church should not support a dependency mentality: those who can provide for themselves should not depend upon the church. The church should not confine its ministry to its own poor. Members should go out in the highways and invite people to come to Jesus.

\section{Biblical Basis for Her Arquments on the Poor}

In this section we look at the biblical basis for Ellen White's teaching on poverty. How does she use Scripture?

Consideration of over three hundred of her documents indicates that the old Testament forms a significant portion of her teaching. One of the passages which influences her teaching is Deut 15:7-11.

If there is among you a poor man of one of the brethren within any of the gates in the land which the Lord thy God gives thee, thou shalt not harden thine heart, nor

\footnotetext{
${ }^{1}$ Ellen G. White, "Our Duty to the Poor," Second Advent Review and Sabbath Herald, November $19,1861,198$.
} 
shut thine hand from thy poor brother: but thou shalt open thine hand wide upon him, shalt surely lend him sufficient for his need, in that which he wanteth. Beware that thou be not tough in thine wicked heart saying that the seventh year, the year of relief is at hand; and thy eye be evil against thy poor brother. - . Thou shalt surely give him, and thine heart shall not be grieved. . . . The Lord thy God will bless you.

While Deut 15:7-11 deals with Israel's poor, Ellen White applies it to the poor, the sick, and the aged. Just as ancient Israel made provision for its poor, every church is expected to take care of its poor. Included in this text is the promise of blessing that those who minister to the poor would receive: "The Lord shall bless thee in all thy works." Ellen White says that there are spiritual blessings to be gained in ministry to the sick, aged, and the poor.

There is a vital part of the passage that Ellen White does not clarify: "For the poor shall never cease out of the land." She does not say if this statement is predicting what will happen or if it is prescribing and therefore confining some people to poverty. Another question for which I did not find an answer in the materials examined is, "If poverty in the Levitical system was relative, how does it compare to poverty as we see it in our societies?"

God provided laws so that if the poor were in need of money they could borrow from the rich. The lender was not expected to charge interest to those who borrowed from them. The biblical basis for this principle is found in Exod 22:25 and Deut 23:19. The principle behind this is 
that the rich should not be motivated by interest when lending to the poor, but only by love for the poor.' she noted also:

The Hebrews were enjoined at all times to assist their needy brethren by lending them money without interest. To take usury from a poor man was expressly forbidden. "If thy brother be waxen poor, and fallen in decay with thee; then thou shalt relieve him: yea, though he be a stranger, or sojourner, that he may live with thee. Take thou no usury of him, or increase: but fear thou God, that thy brother may live with thee." Leviticus $25: 35-37.2$

God not only provided a system where the poor could get no-interest loans, He also provided a safety net within the system. The poor were not required to pay back the principal until the year of relief. If they were not able to pay the principal in the year of relief, their debt would be cancelled. In spite of these provisions, the rich were expected to make loans available to the poor.

Provision was also made for the poor to get food to eat. Farmers were asked not to take up the grain that fell on the ground and not to reap the hedges of their field. Every sixth year the land should be allowed to rest, thus reminding the people that the land belonged to God. During the time when the land was resting, the poor could reap what grew on the land. "This provision was made to ease suffering, to bring some rays of hope, to flash some gleam

${ }^{1}$ Ellen G. White, Prophets and Kings (Mountain View, CA: Pacific Press Pub. Assn., 1917), 647.

${ }^{2}$ Ellen G. White, Patriarchs and Prophets (Mountain View, CA: Pacific Press, 1890), 532. 
of sunshine into the lives of the suffering and distressed."1 Ellen White argues that the Levitical system cannot be improved upon in terms of its provision for the poor and needy. But she also points out that the system did not always work because of selfishness.

The outlook was particularly discouraging as regard to the social conditions of the people. In their desire for gain, men were adding house to house, field to field. See Isa. 5:8. Justice was perverted, and no pity was shown to the poor. of these evils God declared "The spoil of the poor is in your houses. - - Ye beat my people to pieces, and grieve the face of the poor" Isa. 3:14-15. Even the magistrates, whose duty it was to protect the widows and the fatherless. Isa. $10: 1,2.2$

Ellen White based much of her teaching concerning the poor on the book of Isaiah. Jesus began His ministry by referring to Isa $61: 1,2$. In an article in the Advent Review and Sabbath Herald, she wrote that God has chosen mercy, tenderness, and compassion. She suggested that if this fact had been instituted there would be compassion for the poor, fatherless, and the needy.

She commented on the use of the tithes in providing for the needs of the poor. Every third year the tithes were used to provide for the Levites and the poor, "that they may eat within thy gates, and be filled" (Deut 26:12). She said that these tithes provided funds for the use of charity and hospitality. She observed that while the first tithes were

\section{I'Ibid., 534.}

${ }^{2}$ Ellen G. White, "The Call of Isaiah," Advent Review and Sabbath Herald, March 4, 1915, 3 . 
for the exclusive use of the Levites, second tithes were set aside to help the poor.

If the old Testament provides a basis for Ellen

White's teaching on poverty, the New Testament, especially the teachings and the examples of Jesus, is the principle upon which she based much of her practical teaching on how to relate to the poor. She begins by referring to the fact that Christ identified with the poor in the choice of the place of His birth. He was not born in a palace; rather He was born in a manger. His parents were poor; at His dedication they could afford only the poor peoples' gift.

But a design that the world's Redeemer should lay off His crown, lay aside His kingly robe, and come to our world as a man. He clothed His divinity with the garbage of humanity that He might stand at the head of the human family, His humanity mingled with the humanity of the fallen race because of Adam's disobedience. The poverty and humiliation of the son of the infinite God teaches lessons that few care to learn. There is a link that connects Christ with the poor in a special sense. . . . Since the Lord Jesus accepted a life of poverty, no one can justly look with contempt upon the poor. . . . Accepting poverty, that He might understand how the poor are treated in this world.

Thus she makes a significant contribution to the doctrine of the kenosis by suggesting that one reason why Jesus came in poverty was so that He could understand how the poor are treated. This quotation comes from a difficult time in the United states. Ellen White was in favor of the gospel going to the Blacks in the South. It was the self-

\footnotetext{
${ }^{1}$ Ellen G. White, The Southern Work (Washington, DC:
} Review and Herald, 1899), 85. 
emptying of Christ and His identity with the poor which provided a basis for the work among those people.

Another passage that Ellen White used to build her teaching on the poor is the account in Luke 7:19-23, when John the Baptist inquired through his disciples if Jesus was the Christ. Jesus did not respond to the question, but said: "Go your way, and tell John what things you have seen and heard; how that the blind see, the lame walk, the lepers are cleansed, the deaf hear, the dead are raised, to the poor the gospel is preached." (John 11:5) Ellen White used this passage to encourage the church to follow the example of Jesus in working for the poor. If Jesus worked with the poor, His modern disciples should continue to work with and for the poor.

She comments on the feast at simon's house. She suggests that the money that Mary used to buy the perfume was not a waste of resources, because it was for a special occasion. She states that Judas was not primarily concerned about the poor; rather he wanted to control the funds. "Had Mary's ointment been sold and the proceeds fallen into his possession the poor would have received no benefit." 1

Ellen White used the Beatitudes to clarify her teaching on the poor. Commenting on Matt 5:7, "Blessed are the merciful for they shall obtain mercy," she stated that

${ }^{1}$ Ellen G. White, The Desire of Ages (Mountain View, CA: Pacific Press, 1940), 559. 
there is a great need to exercise mercy. "The poor are all around us, the distressed, the afflicted, sorrowing, and those who are ready to perish."1 She appealed to those with means to be merciful to the poor. She suggested that one reason why God has given some people means is that He wants them to share with those who are in need. "Man is to cultivate the tenderness and compassion of Christ; he is not to separate himself from the sorrowing, the afflicted, the needy and distressed."2

From the above we can see that her appeal to be merciful to the sorrowing, the afflicted, the needy, and the distressed is Bible-based. One of the principles behind her teaching is that humankind should be merciful to each other, especially to those who are weak. There is a plea for us to become caring people.

The words with which Jesus began to teach, "Blessed are the poor in spirit, for theirs is the kingdom of heaven" (Matt 5:3), are used to lay a foundation for her teaching on the poor. Was Jesus talking about the economic poor? Ellen White clarifies what Jesus meant when He said "Blessed are the poor in spirit" by answering the question, who are the poor in spirit?

Do you ask what it means to be poor in spirit? The next verse is of like character and says "Blessed are

495.

${ }^{1}$ White, Welfare Ministry, 15.

${ }^{2}$ White, "Blessed Is He That Considereth the Poor," 
they that mourn, for they shall be comforted." To be poor in spirit means that we feel our deficiency and need because we have sinned and come short of the glory of God. It is this that causes us to mourn. . . . To be poor in spirit is to never be satisfied with present attainments in the Christian life, but to be ever reaching up for more and more of the grace of Christ. The poor in spirit is one who looks upon the perfection of Jesus' character and sees his own unlikeness to Him who is glorious in holiness."

From the above we can conclude that Ellen white does not interpret "the poor" as relating to the economic poor. This would not be consistent with her previous teaching, for she does not see poverty as an ideal state. It seems clear from her comments that she understands "poor in spirit" to refer to spiritual poverty--those who in the light of God's holiness feel their own poverty of spirit.

\section{Conclusion}

Concern for the poor is a significant part of Ellen White's writings. She not only wrote above poverty, but both she and her husband gave practical help to the poor. She wrote about the plight of the poor in France, England, Australia, and her native country, the United states. At a time when Black people in the southern part of America were downtrodden and many lived in poverty, she demonstrated great interest in their cause. Many times when she spoke about poverty in the South, she did not meet with the approval of the brethren.

\footnotetext{
'Ellen G. White, "The Beatitudes," signs of the
} Times, May 9, 1892, 487. 
Ellen White approached the discussion on poverty methodically. One of the first questions that she raised was, What is the cause of poverty? Why are some people poor? She stated that the causes of poverty were twofold: personal and external. Her major emphasis is on personal reasons. It seems to me that her middle-class American view may have influenced this position.

While she spoke about misfortune being a cause for poverty, she did not address one of the main causes for poverty--the role of oppressive government. Perhaps it is because governments were not oppressive during the time that she wrote.

She does not suggest that all poor should be helped. She is in favor of helping those poor who are in need. Because of this she classified the poor into two groups: "the Lord's Poor" and those who "are not the Lord's Poor." She argued that this last group might deplete the church fund.

Ellen white does not deal adequately with the question, Is poverty a part of God's will? she is clear on the fact that poverty is caused by human action. It could be that as a good theist she never had to deal with this question. If one should look at the many times that she mentions, "The poor will be with you always," one could be led to believe that poverty is a condition which was established by God. 
Ellen White concludes that each church should take care of its poor. Churches should not shift their responsibility by expecting institutions to take care of their poor. She suggests that the members of the church should open their homes to the poor on Thanksgiving. The most significant factor which contributed to her teaching on the poor is the Bible, both the New Testament and the old restament. She holds up the Levitical system as the ideal society. She states that humankind cannot improve upon that system. She does not recognize the difference between ideal and practical, for, while she holds up the Levitical system as the ideal, she states that Israel did not always live up to the ideal because of $\sin$ and selfishness.

A major portion of her teaching is based on the words and examples of Jesus. It is from the teachings of Jesus that she sets out her own teaching of concern for the poor. 


\section{CHAPTER 5}

\section{A STRATEGY FOR MINISTRY TO THE POOR IN NORTH LONDON}

This chapter reviews what has been done by the Seventh-day Adventist Church in North London. It then describes the strategy to be used.

\section{The Adventist Church in North London}

The Seventh-day Adventist Church in London is divided into four geographical areas: East London, North London, South London, and West London. The first two divisions are northeast of the River Thames; the second two divisions are southwest of the River Thames.

Each church within these four divisions has a Community Services Department which supervises and promotes welfare within the church and community services in the community. The four divisions come together in the London Community services Federation, which coordinates community services in all London. The Community Services Director of the South England Conference is the coordinator and facilitator for the Federation.

This study is mainly, though not exclusively, concerned with what the church in North London is doing. 
The Halloway Seventh-day Adventist Church is involved in various activities in the community. For example, on the second Sunday of each month, the church distributes an average of four hundred cooked meals to people who sleep rough. Those who sleep on the street have stated their preference for hot meals. A typical meal consists of rice, green peas, vegetarian meat, vegetables, bread, and a hot drink.

The Halloway Church serves as a temporary depot and distributor of surplus food from the European Community. Among the food that is distributed to the poor and needy in the community are oil, butter, and meat.

The church Community Services has a good variety of clothing. Individuals meet on Tuesdays to sort, label, and distribute clothes. The police in the Halloway area usually refer those who are in need of clothes to the community Center at the Halloway Seventh-day Adventist Church.

A summary of the work that has been done by the Halloway Community Services shows that in one year it distributes approximately 5,000 meals to those who sleep on the street. It distributes approximately 2,000 items of clothing. It also distributes approximately 15,000 items of food from the European Community (see Appendix A).

It is not easy to estimate how much is spent by the Community Services Department in providing these services. The Halloway Church votes an annual budget of $£ 2,000$ to the 
Community Services Department. The department must balance this sum between the needs of the local church and the needs of the community.

The Community Services program is heavily subsidized by the members of the Community Services Department. These members not only contribute their time but also contribute financially to the program. A "guesstimate" of the cost of the work that has been done suggests that it is in the region of $£ 10,000$ annually.

The amount above does not take into account funds that individual members give to those who "drop into the church." For example, at any time when the church is open, individuals "drop in" and ask for money. On Wednesday nights, sunday evenings, and Sabbaths, people will come to the church expecting their needs and wants to be met.

The South England Conference, which is the immediate higher organization to which the Adventist churches in London belong, does not contribute financially to the Community services programs in these churches. The program for feeding those who sleep on the street is the exclusive responsibility of the local church.

\section{The strategy}

The origin of the word "strategy" comes from a military background. For example, Webster's Third New International Dictionary defines strategy as: "the science and art of employing the political, economic, psychological, 
and military forces of a nation to afford the maximum support to adapted policies in war." A secondary meaning for strategy is "the art of devising or employing plans or stratagems toward a goal." ${ }^{1}$ c. Peter wagner adapts this meaning of strategy to formulate his definition of strategy for mission: "Strategy is a mutually agreed means to achieve the ends which have been determined by a particular group." 2

Some individuals are skeptical about strategies in mission. They argue that Jesus has promised to be with those who are involved in mission and that He gives the Holy spirit to guide in all mission activities, therefore there is no need for strategy. ${ }^{3}$ Wagner, while agreeing that the Holy Spirit is vital for all mission, suggests that there is need for strategy in mission. He does not think that strategy is incompatible with the work of the Holy spirit. He argues that strategy was never intended to rival the work of the Holy Spirit; rather, it was intended to supplement and facilitate the work of the Holy spirit. He further states, "Good management and careful planning have a

\footnotetext{
'Webster's Third New International Dictionary, 1961, s.v. "Strategy."

${ }^{2} \mathrm{C}$. Peter Wagner, Frontiers in Missionary strategy (Chicago: Moody Press, 1971).

${ }^{3}$ Ibid. , 15.
} 
definite part in all phases of the work of the kingdom of God, not excluding mission."1

When we look back at the mission of the apostle Paul, there seems to be two strategies at work. On the one hand, Paul was led and directed by the spirit. For example, Paul tried to preach in Asia but the Spirit did not allow him. While he was in Troas he waited for the direction of the Spirit, which led him to Macedonia. ${ }^{2}$ on the other hand, when we look at the places where Paul established churches, there seems to be a deliberate strategy. For example, Paul established churches in

centers of Roman administration, centers of Greek civilization, centers of Jewish influence or of some commercial importance. After Paul had established churches in these centers, He selected a leader and then he moved on to another center. ${ }^{3}$

Wagner suggests that there are three vital elements in a mission strategy. The mission strategy should be Bible- centered; its primary source should be God's Word. The mission strategy should be efficient; by efficient, he means that those who are involved in mission strategy should be able to manage personnel, time, and money. The mission strategy should be relevant; there should be constant

$$
{ }^{1} \text { Ibia. }
$$

${ }^{2}$ Roland Allen, Missionary Methods: st. Paul's or ours (Grand Rapids, MI: Eerdmans, 1962), 10.

$$
{ }^{3} \text { Ibid. , 13-15. }
$$


revision of the strategy so that strategy can remain relevant. ${ }^{1}$

The Strategy for Ministry to the Homeless in North London will be Bible-based. The Exodus narrative reveals God's deliverance from bondage in Egypt. Deut 15:1-11 shows how provision was made for the poor through the Law of Release. Matt $25: 31-46$ reveals that humankind will be judged based on how it treats those who are in need. Luke 4:16-20 indicates that Jesus came to institute the new Jubilee when the poor would be set free. These Bible passages and the writings of Ellen G. White will provide the basic foundation for this strategy.

The strategy will be efficient by the awareness of the stewardship of personnel, time, and finance. At all times we will be aware of our accountability to God. We will make a special effort to see that funds are utilized in the most productive way possible.

The relevance of the strategy will be shown by constantly assessing the program to see if it is achieving its goals. The strategy will need to be dynamic so that it can adjust to change.

C. Peter Wagner, in speaking about the importance of having goals in constructing strategy, states, "If there are no goals, no strategy can be developed. Therefore, a thorough understanding of mission goals is the first step

\footnotetext{
${ }^{1}$ Wagner, 16 .
} 
toward the formulation of an effective strategy."1 He further states that goals should have biblical priorities and that these priorities should operate in two dimensions, the horizontal and the vertical. The relationship with God, which is the vertical dimension, should inform our practice on the horizontal dimension, which is the relationship with humankind, especially those who are in need. ${ }^{2}$

This strategy will operate on the two dimensions suggested above. On the one hand, the strategy has its primary base in the Word of God, thus meeting the vertical dimension. On the other hand, the central focus will be on those who are in need, thus meeting the horizontal dimension.

While those who sleep on the street in London have many needs, this strategy will seek to achieve the following goals or objectives in the targeted area.

1. It will provide 300 meals each day.

2. It will provide a house which will make an address available.

3. It will provide warm clothes during the winter.

4. It will help those who sleep on the street to become self-sufficient.

5. It will direct individuals to the relevant agencies.

\footnotetext{
${ }^{1}$ Ibid. , 17.

${ }^{2}$ Ibid. , 18.
} 
6. It will work with and cooperate with other religious organizations.

Five steps will be followed in implementing the strategy. They are: Analysis, Goals, Step-by-step Plan, Resources, and Evaluation.1

\section{Analysis}

Since 1948, England has been a welfare state. The Social security provides free medical and dental services. The unemployed get a weekly allowance and their rent is paid. Education is provided by the taxpayers. ${ }^{2}$ In spite of these benefits, which come from the public purse, there are those who fall out of the "safety net" into the "poverty trap."

Many of those who fall into the "poverty trap" are professionals who have met misfortune and have become disillusioned with life. Some are young people who have been attracted to the city. Others are loners who become part of the urban drift.

Every night approximately four hundred individuals "sleep rough" in the targeted area in London." These individuals are exposed to the elements. They do not have a

${ }^{1}$ Duane H. Elmer and Lois McKinney, eds., With an Eye on the Future: Development and Mission in the 21 st century (Monrovia: MARK, 1984), 125-126. state." ${ }^{2}$ Encyclopaedia Britannica, 1971 ed., s.v. "Welfare ${ }^{3}$ Editorial, 65 . 
91

permanent place to sleep. Some move from shop front to shop front, while others sleep in the parks. 1

These individuals who "sleep rough" come from

various backgrounds and fall into various age groups and

gender. During the day some of them try to get odd jobs.

others try to find permanent employment and some spend their time in the parks or walking the streets. ${ }^{2}$

These people face several needs. Among them is the need for a permanent address if they are to receive social security benefits, regular dental and medical care, and if they are to be employed.

The young people who are a part of this group need to get employment so that they can improve their status. Many of these youth have dropped out of school, thus they do not have marketable skills. There is a great need to train them so that they may become employable.

One of the important needs of those who "sleep rough" is the need for food. The odd jobs that they get are not enough to provide them with food from day to day. Some have told me that for up to five days they have not had a cooked meal.

Many organizations have tried to address the need for food that these people have, among them the salvation

${ }^{1}$ During a period of six months I spoke to some of these individuals who sleep at the store fronts on Tottenham Court Road.

${ }^{2}$ Moore, Carter, and others, 56. 
Army. The Seventh-day Adventist Church in North London and the Social Services, however, attempt to deal with the situation seasonally and sporadically. It is not enough. The Salvation Army provides a meal every Sunday in the targeted area. The Seventh-day Adventist Church in North London provides a meal one Sunday per month. The Social Services agencies provide food on Christmas and New Years Day •

There are several areas of weakness in the approach that these organizations have taken; among them is the lack of coordination. For example, at times they duplicate each other. I have seen two vans with food at the same spot, while other areas have been neglected. The seasonal approach does not satisfy the need for food during the week or the rest of the year. ${ }^{1}$

There is a great and urgent need for a consistent ministry to those who "sleep rough" in North London. The main purpose of this strategy is to meet a physical need by providing these people with a daily meal, providing them with warm clothes during the winter, directing them to relevant authorities, cooperating with other religious groups, and ministering to their spiritual needs with the hope of leading them to faith in Christ.

${ }^{1}$ During the Christmas season organizations make a desperate effort to provide those who sleep on the street with a Christmas meal. It does not seem that these organizations are concerned about how these people live during the rest of the year. 
Goals

We start with the assumption that there is sufficient food in North London to meet the need of those who have fallen into the "poverty trap" and are forced to "sleep rough." We can see that it is possible that the time will come when those who "sleep rough" will have an acceptable standard of living.

We envision food being distributed daily. Vans with hot food will cover every area so that no poor person in the area of North London will go without food. We hope that this program will be so effective that it will spread to cover all of London. The objective should be that every person in the "poverty trap" should be able to get a hot meal every day.

We hope that as the program grows we will be able to provide those to whom we minister with an address. This address will provide them a place to receive letters. This address will enable them to be registered with a doctor or dentist. They could also use the address on employment forms.

We hope to encourage the young to enter the government Youth Training Program. This program will not only provide them with marketable skills, it will also provide them with a weekly allowance. We can see some of these youth gainfully employed in the future, thus enabling them to move off the streets. 
We hope that there will be cooperation between all the organizations which are currently trying to meet the need of those who "sleep rough" in North London. We can see both government and non-government organizations working together to fulfill this need.

We hope to gain the confidence of those to whom we minister. It is one objective of this program to present Christ to these individuals. We believe that many will be led to faith in Christ. We hope that those who are led to faith in Christ will become bridges to other people who are sleeping rough.

We do not envision that this ministry will permanently depend on the personnel of the church or its resources. When a viable ministry is established, we hope to turn over the ministry to the "bridge people." We will then move on to another area of London.

We think that through this ministry many people will be led to christ in the long term. This ministry will provide an answer to those who ask, What is the church doing for society? We hope that those who are critical about the church will have a new concept of the church.

The specific area of North London that we hope to target is the Embankment. This area is frequented by more than 400 individuals who live and "sleep rough."

The specific needs that we hope to meet are: to provide 400 meals each day; to provide warm clothes and 
blankets in the winter; to lead them to the relevant organizations; to cooperate with other religious organizations while leading some people to Christ.

The time period that we will set for turning over the ministry to the "bridge people" is eighteen months. We will then move to another area in London.

\section{Description of the strategy}

The strategy will be divided into three stages. The first stage will be to motivate, empower, and sensitize the church. This will be done through a series of four sermons and a series of group discussions. The second stage will be implemented through a series of meetings with church and public officials. The third stage will be practical preparation for implementing the strategy.

\section{Sermons to Sensitize, Empower, and Motivate the Church}

The Halloway Seventh-day Adventist Church has a membership of 750 members. Of the 750 members, less than 10 percent of the membership actively participates in community services. For the strategy to become viable there will need to be a pool of 120 persons from which to choose workers. Presently, senior citizens, mainly retirees, form the core of those who participate in the ministry to those who are in need. There is an urgent need to supplement the core of seniors with other individuals. For example, the project 
needs more males, individuals in the 40-50 age group, and young people.

In order to sensitize, empower, and motivate the church, a series of four sermons will be presented during the divine hour on Sabbath. The theme of these sermons will be "My Brother's Keeper." The topic for the first sermon will be "My Brother's Keeper." The second sermon will be "Let Us Share, We Are Brothers." The third sermon will be "Fasting and Acting." The fourth sermon will be "Pure Religion." A response card will be given at the end of each sermon. (See Appendix B for outline of the sermons.)

\section{Discussion Groups}

In order to reinforce the sermons, discussion groups will be held on four Wednesday nights following the sabbath sermon. The Sabbath School unit will provide the basis for these discussions. On the Sabbath after each sermon the Sabbath School teacher will be given the outline for the group discussion on Wednesday evening. The theme of these discussions will be Ellen White's Teaching on the Poor. Each group will hold discussions for thirty minutes, after which someone from the group will present a brief report, which should not be more than three minutes. There will be general reaction to the reports for fifteen minutes. The meeting will conclude with a summary by a designated person. (See Appendix c for discussion outlines.) 
Meetings with Organizations

Meetings with organizations will fall into four categories: the local church, the conference, religious organizations which are not Seventh-day Adventist, and government organizations.

The first set of meetings will be at the local church level. The contact person will be the community Services leader. There are important reasons for these meetings. For example, the nucleus of workers for the strategy will come from this department. The community Services leader will be the person who will present the strategy to the Church Board.

The second set of meetings will be with the London Federation of Community Services. The contact person will be the secretary of the Federation. These meetings will be vital because the discussion of the strategy will move to the next level. The Federation includes all the churches in London and their support is vital for this strategy and any future strategy.

The third meeting will be with the South England Conference Director. We will request that the director present the strategy to the conference and serve as the contact person with the South England Conference. We will request that the director meet with the London Community Services Federation. We will ask the director to call a 
meeting with the pastors in London with the hope of getting their support for the strategy.

\section{other Religious Organizations}

The main religious organization in England which is involved in charitable work is the Salvation Army. The Salvation Army predates the welfare state in England. It is vital that we meet with this organization so that we can draw on their expertise. For example, they are experienced in providing homes for the homeless and in feeding the poor through soup runs. We would like to see how we could coordinate our efforts and avoid duplications in ministering to those who sleep rough in North London. The contact person will be the senior officer in North London.

There are other religious bodies; for example, the Church of England, which sponsors the Charity Homeless Concerned. This charity could provide valuable information about people who sleep on the street. The Methodist Church is another religious body with experience in working for the poor and homeless. We would seek to find out about their involvement in North London and coordinate our efforts so that it could be more effective and duplication of services could be avoided.

\section{Meetings with Government Organizations}

The first contact with a government authority will be with the Commissioner for charities. The purpose for 
this meeting will be, first, to apprise the commissioner of the goals and objectives of the project. The second reason will be to register The strategy for Ministry to the Homeless in North London as a charitable organization. Charitable status will provide the project with legitimacy and with other benefits. For example, the project will be given a tax exempt status; it will be able to publicly solicit funds; and its books will be open to public audit. The European Community, through its representatives in London, have contributed food for the poor and homeless. We hope to present the project to the community representative and seek contributions in cash and kind from the organization. Based on past experience, we anticipate substantial contributions in oil, meat, and butter.

\section{Practical Plans for Implementing the strategy}

We will delegate the work, territory, and responsibilities among the different organizations. We will explain to the participants that the program will be assessed on an ongoing basis, however, we would ask them to commit to work for the project for twelve months with the option for an additional six months. At the end of eighteen months, the project will be turned over to some of the people to whom we minister.

While it is the strategy's expectation to keep expenses at a minimum, we will need to employ ten people and 
provide a stipend for another fifteen individuals. Among the categories of workers who will be employed will be six cooks and four drivers. Among those who will receive a stipend will be seven cook assistants and eight servers and packers.

Three weeks before the date that the project will start, we will begin to purchase nonperishable products. These products will be stored at the Halloway Seventh-day Adventist Church. Two weeks before the day that the project will start, a rota will be posted detailing those who will be on duty for the next three weeks. On the Friday nearest the sunday on which the project will begin, perishable products will be purchased. On the sunday, food will be cooked and transported by vans to the designated area in North London.

\section{Bridge People}

After the second week of the project we will begin to look for potential bridge people. These individuals will become the link between the project and those who sleep on the street in the target area. By the third week we will recruit ten individuals from among those who sleep on the street. We will employ these individuals to serve in the cooking, preparation, and distribution of meals. We will have devotions each day before the preparation of food. Before food is distributed we will have prayer. While food is being distributed we will distribute religious and health 
literature. It is hoped that the original ten will learn to manage and run the project and that they will recruit others from those who sleep rough. It is from the original ten that we hope to gain the first converts.

\section{Drop-In Center}

A house will be rented or leased with an option for purchase near the targeted area. The ideal type of house would contain five bedrooms. Five showers will be installed on the top floor and one on the ground floor. These showers will be made available to those who sleep on the street. Four telephones will be installed and made available to the people that the project has targeted. There will be a maximum limit of five minutes for each call and each person will normally get two calls a day. However, in exceptional circumstances an additional call may be allowed.

The rooms on the top floor will provide temporary shelter for those who are not able to find a place to sleep. The sleeping facilities on the top floor will be for women while the main floor will be for men. only in an exceptional case will anyone be allowed to stay in this center for more than a week at a time.

The kitchen will be equipped with two hot water urns so that those who drop in at the center will be able to get a cup of tea or soup. In the evenings between five and nine a light supper will be available. It should be noted that 
some of the services that the center provides will be temporary.

One significant function that the center will provide for those who sleep on the street will be an address. This address will provide them with a place to receive correspondence. They will be able to use this address when applying for jobs and when registering for medical and dental services.

\section{Resources}

The greatest resource for any project is people. The Halloway Church has a membership of 750 . It is one of the oldest Adventist churches in London. The church has a strong Community services program. For more than twenty years, the church has been providing food and clothing for those who are in need in the community.

The church has a good kitchen, including an industrial stove, with sufficient space to prepare 500 meals. It also has sufficient place for storing food. The nucleus of human resources will come from the Halloway Church, the London Community Services Federation, which includes all the Seventh-day Adventist churches in London, with an estimated membership of about 11,000. The Federation is able to provide additional human resources that will initially manage the program.

Individual churches have provided between 200 and 450 meals for distribution. Several churches (for example, 
Halloway, Brixton, and stoke Newington) have their own vehicle which can be used to transport food to the Embankment area. In time, there will be a need for other vehicles, but the current fleet will be adequate to do the job.

One area that we need to examine is finances. It is possible to finance the project from the following resources: the local churches, the Federation, London Lay Advisory, the South England Conference, government grants, and charitable donations.

The Halloway Church, between 1991 and 1995, voted an annual budget of $£ 3,000$ for Community services. The Federation has the potential to donate $£ 4,000$ annually. The South England Conference usually gives £5,000 to "worthy causes." The government, through the European Common Market, can make a significant contribution of butter, meat, milk, peas, and oil.

The greatest untapped resource which has not been employed is charitable donation. The British public gives substantial amounts to charity annually. It is estimated that they contribute between $\$ 12-16$ billion annually. ${ }^{1}$

For the church in North London to get a charitable status would call for changes in the South England Conference and the British Union who hold charitable status

\footnotetext{
"John Bird, "Let's Do Business for the Underclass," Guardian, November 29, 1997, 1-2.
} 
for the churches. The church in North London would receive great benefit if it could register as a charitable organization. Registration would provide the church with the opportunity to write to organizations and advertise for public donations during the year. The church in North London would not be limited to three weeks of public solicitation during Harvest Ingathering.

Having examined the resources that are available, it seems that there are sufficient resources available so that the program to minister to those who "sleep rough" at or near the Embankment can be implemented.

\section{Evaluation}

The strategy will contain mechanisms for evaluation. While the aim is to get the workers committed for eighteen months, there will be ongoing assessments which will be reviewed every six months. We will evaluate if the food is reaching the target people. We will evaluate the workers' response to the program.

The cost factor will be taken into consideration. It is our objective to keep the administrative expenses to 5 percent of the budgeted amount. Thus, 95 percent will be spent on providing food for the needy.

While we set out to provide 400 meals each day, we must recognize that the number of meals that will be served will depend on the actual budget. Depending on the budget, 
we might have to adjust the number of meals served each day or change the number of days that we serve food.

One area which will need careful evaluation is the spiritual impact of the program. It is a stated objective to lead some people to faith in Christ. Those who will be led to faith in Christ will become "bridges" to other people. They will become the nucleus who will take over administration of the program.

We will need to recognize that leading people to Christ might not necessarily result in their becoming Seventh-day Adventists. Those who work with this project should become aware that the best way to evaluate the strategy will be by the service rendered.

The strategy should not be adjusted to make seventhday Adventists of the people to whom we minister at the Embankment. Our first task is to feed the hungry. our second task is to lead them to faith in christ.

will we be able to turn over the project to the "bridge people" in eighteen months? While we might have to make some adjustment to the program in terms of the time period, the project should not remain permanently in the hands of the North London Seventh-day Adventists. At most, after twenty-four months the transition should be completed.

\section{Conclusion}

There will always be the possibility that a strategy might not work, however, I believe that this strategy will 
be successful because it is based on the command of Jesus that we should show concern for the poor. I believe that with the aid of the Holy spirit and dedicated workers, the Lord will lead us into a productive ministry.

My great fear is how the church will evaluate this ministry. This ministry may not quickly produce baptisms. There may be no offerings from this ministry, but there will be an investment in humankind and a transformation of some to faith in Christ. 
CHAPTER 6

SUMMARY, CONCLUSION, AND RECOMMENDATIONS

\section{Summary}

This study has reported that there are approximately 400 individuals who sleep rough on the streets of North London. Those who sleep rough have many urgent needs. Among these needs are: (1) the need for food that will provide them with a balanced diet; (2) the need for a permanent address; (3) the need to access the social security system; (4) the need for warm clothes during the winter; (5) the need for medical and dental care; and (6) the need to be trained with marketable skills.

Some organizations such as the Salvation Army, the Seventh-day Adventists, and the Hare Krishnas are meeting some of the needs of those who sleep on the street. There is, however, a need for a coordinated effort among these organizations.

The biblical evidence which was examined suggests that: (1) God is concerned about those who are oppressed; (2) God made provision for the poor through the Law of Release; (3) that humankind will be judged based on how they 
relate to those who are in need; and (4) Jesus' ministry demonstrates that the Jubilee was time for liberation.

The writings of Ellen G. White state that some of the reasons why people become poor are personal while others are external. She suggests that the church should care for those who are in need because, in caring for the needy, they are following Christ's example.

A strategy was constructed to deal with specific needs of those who sleep on the street in North London: to provide 400 meals each day; (2) to provide warm clothing during the winter; and (3) to provide a house with an address.

Five steps were employed in developing the strategy and they are: (1) Analysis, (2) Goals, (3) step-by-step Plans, (4) Examination of Resources, (5) Evaluation.

\section{Recommendations}

As a result of this study, the following points are recommended:

1. That the South England Conference of Seventh-day Adventists become involved in the project to minister to those who sleep on the street of North London by initially contributing $£ 10,000$ annually

2. That the South England Conference establish a program to encourage pastors in the inner city to support and participate in the ministry to those who sleep on the street 
3. That the South England Conference permit the church in North London to be registered as a charitable organization

4. That the South England Conference give study to establishing a Welfare Community Center in North London

5. That the London Lay Advisory contribute $£ 5,000$ annually to the project for those who sleep on the street in North London

6. That the London Community Services Federation contribute $£ 5,000$ to the North London Project

7. That the church in North London increase the annual budget for the Community services Department

8. That the church in North London seek actively to cooperate with other religious and charitable organizations

9. That a special effort be put in place to recruit young volunteers for the program

10. That the officers of the project develop a good relationship with representatives from the European Community

11. That material be printed for the purpose of soliciting funds and providing receipts to donors

12. That good bookkeeping practice be established

13. That an annual, public audit be conducted

14. That a special committee of seven persons be named to direct the project 
15. That within the eighteenth to twentieth months, the project be turned over and managed by those street people who have benefited from the program

16. That study be given to take similar programs to other areas of London

17. That the Halloway church be used as the initial venue for the preparation of food

18. That methods be in place to evaluate the program.

The following are also areas recommended for further study:

1. Sexual violence as a reason why women become homeless and are forced to sleep on the street

2. The cause of homelessness among the unemployed (45-55 age group who have become unemployed) who are sleeping on the street

3. The psychology of those who sleep on the street with a focus on the mental process which leads some individuals to adapt to life on the street

4. The theology and praxis of the seventh-day Adventist Church in London as it relates to ministry for those who sleep on the street.

\section{Conclusion}

People who sleep on the street in North London have many problems. For example, the lack of a permanent address deprives them of the benefits that the state provides. The 
lack of proper diet and medical care has resulted in these individuals having a shorter life expectancy than the average population.

Individuals have adopted several ways of looking on those who sleep on the street. For example, some individuals argue that those who sleep on the street are addicts, drunks, and losers. There are other individuals who look at those on the street as persons who have fallen on misfortune who are in need of care.

The church in London has not done enough to meet the physical and spiritual needs of those who sleep on the street. There is even disagreement among some members about the need or viability of this type of ministry. Some have suggested that it is a waste of time and money. One meal each month cannot meet the needs of those who sleep on the street.

The South England Conference needs to provide a full-time Community Services Director for London. Before the Conference gets actively involved in the ministry to those who sleep on the street, there needs to be the clarification of some concepts.

The main concept which needs clarification is "gospel." Many times when words such as poverty, oppression, and injustice are used in the context of the gospel, the person who used these words is perceived to be "a radical who is preaching the 'Social Gospel'." 
A reading of Matt 25:31-46 and Luke 4:17-20 suggests that Jesus did not make' any distinction between "the social gospel" and "the gospel." Jesus' ministry brought liberation to the oppressed, healing to the brokenhearted, and help to the needy.

There is need in North London for a strategy for ministry to those who sleep on the street. Those who participate in this strategy should not expect quick success. The success of this strategy should not be measured in terms of baptism and offerings. The real measure of the success of this strategy should be how the needs of those who sleep on the street are met.

I have gained new insight into the various reasons why people sleep on the street and these reasons are many. Most of those who sleep on the street are driven there because of circumstances, in most cases, beyond their control. The main reason why people are reduced to sleeping on the street, however, is because of the lack of affordable accommodation.

Living on the street can be one cause why people develop vices and get sick. For example, while there are people who come on the street with mental illnesses, there are some individuals who develop mental illnesses as a direct result of sleeping on the street.

This project could serve as a pilot that could influence the creation and expansion of other ministries in 
the inner city in London. The project could also have an impact on inner-city ministries in England and the United Kingdom .

This study has made a significant contribution to my ministry. It has helped me to be concerned about the homeless in general and particularly those homeless who sleep on the street. It has created the desire to work for and with those who sleep on the street. It has also created the urge for further study into some of the reasons why people become homeless.

This study should not be viewed as a conclusive or comprehensive document. It is part of an ongoing study which is concerned about ministering to the needs of those who sleep on the street in North London.

This strategy has the potential for development within the Seventh-day Adventist Church in North London or outside the church as part of an independent ministry. Wherever the ministry for those who sleep on the streets of North London is developed, it is hoped that this project will actively demonstrate Christ's exemplary ministry to those who are in need. 
APPENDIX A

QUESTIONNAIRE 
The purpose of this questionnaire is to find out the nature and scope of the Halloway Seventh-day Adventist Community services work with the homeless in North London.

1. How long have you been involved in community services work?

2. What offices have you held in community service?

3. What office do you currently hold in the community Services?

4. How long have you been involved with the church feeding program?

5. Approximately how many persons participate in the feeding program?

6. How frequently does the department feed the homeless?

7. What is the average number of meals that have been served in the last year?

8. What is the estimated cost of each meal? 
9. To the best of your knowledge, how much has Halloway budgeted for community Services in the last five years?

10. Does the South England Conference contribute financially to the feeding program? If not, what do they contribute?

11. Does the British Union Conference contribute financially to the feeding program? If not, what do they contribute?

12. Do you receive help from ADRA? If so, what type of help do you receive?

13. Do you receive any contributions from the EEC? If so, what type of contributions do you receive?

14. Please list the names of any organizations from which you receive help and what kind of help. 
15. What are the objectives of the feeding program?

16. Estimate the hours that you spend in preparing the meals.

17. How many meals have you served in the last six months?

18. How many men participate in the preparation and distribution of meals?

19. How many young people participate in the feeding program?

20. What is the main ethnic group to which the feeding program is targeted?

21. What improvement would you like to see in the feeding program? 
22. List the names of other denominations which have a feeding program.

23. How many Seventh-day Adventist churches in North London have a feeding program? 
APPENDIX B

MY BROTHER'S KEEPER 
Genesis $4: 1-10$

- . And the Lord said to Cain, Where is Abel thy brother? And he said, I know not: Am I my brother's keeper? And He said, What hast thou done? the voice of thy brother's blood crieth unto me from the ground (Gen $4: 9-10$ ).

There was great expectation when Cain was born. When Eve saw the child she exclaimed, "I have gotten a man child. . the Lord." Within years this child who was taught to be the primmest child killed his brother Abel. What was it that led this young man to take his brother's life? Each time there is a murder there is this vital question, why.

Gen 4:3-7 tells that both brothers brought their sacrifice to God. Cain brought fruits from the field. Abel brought a lamb. God accepted Abel's offering but he rejected Cain's. Ellen White, commenting on Cain's offering, said that he knew that he was required to bring a lamb; but because of his rebellion against God he brought fruits. 1

There are three things in this narrative that we would like to explore. 1) God's question to Cain, where is your brother? 2) Cain's question, Am I my brother's keeper? 3) God's question and His comment, What have you done? The voice of thy brother's blood crieth unto me from the ground.

\footnotetext{
${ }^{1}$ Ellen White, Patriarchs and Prophets (Mountain View, CA: Pacific Press, 1980), 68-69.
} 
Where Is Your Brother?

The narrative does not reveal how the murder was committed. We do not know if this was premeditated murder or if it was a crime of passion. The word of God tells us that after the crime God asked Cain, where is your brother? This question was a rhetorical one because God knew where Abel was. The importance of this question was to lead cain to come to terms with his action. ${ }^{1}$

\section{Am I My Brother's Keeper?}

Cain's response was not only evasive, it is filled with significance. "Am I my brother's keeper?" The implication of this answer is the only God can truly keep anyone. If God does not know where Abel is, how could Cain? God ignores the innuendo and He asks Cain, What have you done?

\section{The Voice of Thy Brother's Blood Crieth to Me From the Ground}

Here is a dramatic picture. Blood is crying and God hears the cry. This cry for action should not be limited to the cry of those who have been murdered. "It is the cry of. those who are in need of food (Gen 41:55). It is the cry of those who are oppressed by their enemies (Judg $4: 3$ ). It is the scream for help of a woman being raped (Deut 22:24, 27).

'Gordon $\mathrm{J}$. Wenham, Word Biblical Commentary--Genesis 1-15 (Waco, TX: Word Books, 1982), 106. 


\section{Conclusion}

There are many voices crying in the church and outside of the church. God hears these voices, voices of those who are in need of food; voices of those who are lonely. What have we done which has caused these cries to reach up to God? What are we doing to feed those who are hungry? What are we doing to comfort those who are lonely? We are our brother's and sister's keepers.

\section{Let Us Share--We Are Brothers}

Acts $6: 1-6$

And in those days, when the number of the disciples was multiplied, there arose a murmuring of the Grecians against the Hebrews, because their widows were neglected in the daily ministration. Then the twelve called the multitude of the disciples unto them, and said, It is not reason that we should leave the word of God, and serve tables. Wherefore, brethren, look ye out among you seven men of honest report, full of the Holy Ghost and wisdom, whom we may appoint over this business (Acts 6:1-3).

The apostolic church was a caring church. The Holy

Spirit seems to have touched every area of their lives. The church was motivated by love. Acts 4:32 states that "the multitude of them that believed were of one heart and of one soul: neither said any of them that ought of the things which he possessed was his own, but they had all things in common." Acts 4:34 states that no member of the community lacked anything. Those who were wealthy shared with those who were in need. 
When the church began to grow, new difficulties arose. Some were getting more out of the common fund than others. The spirit of unity within the community was interrupted by those who were not getting their share from the common fund. Acts $6: 1$ says that there was murmuring among the Greek-speaking widows because they were neglected. There was a cry for equitable distribution from the common funds.

\section{The Twelve}

The disciples were confronted with a dilemma. on the one hand, they were occupied with preaching the word. on the other hand, there was the need to minister to the physical needs of the poor in the community. The disciples' response to the dilemma is a clear sign that there needs to be balance between the proclamation of the word and ministering to the physical needs of the poor. The twelve agreed that they would continue in the ministry of the word and they would select seven persons who would minister to the needs of the community.

The standards set for those who were selected to minister to the temporal needs of the community suggest that the disciples placed great importance on this ministry. For example, they "were to be honest, full of the Holy Ghost and wisdom." One of those who was selected, stephen, demonstrated that he was not only capable of ministering to 
the physical needs of the community, he was also competent in the ministry of the word.

\section{Conclusion}

The disciples did not create a division between ministry to the physical needs and ministry of the word. The church should follow the example of the early church. We need to maintain the tension between the ministry to the physical needs and ministry of the word.

\section{FASTING AND ACTING}

Is it such a fast that I have chosen? a day for a man to afflict his soul? is it to bow down his head as a bulrush, and to spread sackcloth and ashes under him? will thou call this fast, and an acceptable day to the Lord? Is not this the fast that I have chosen? to loose the bands of wickedness, to undo the heavy burdens, and to let the oppressed go free, and that ye break every yoke? Is not to deal thy bread to the hungry and that thou bring the poor that are cast out to thy house? when thou seest the naked that thou cover him; and that thou hide not thyself from thine own flesh? Then shall thy light break forth as the morning, and thine health shall spring forth speedily and thy righteousness shall go before thee, the glory of the Lord shall be thy reward.

Israel was concerned about God's response to their fasting; they confronted God with a series of questions: Why have we fasted and You have not seen it? Why have we humbled ourselves and You have not noticed? God responded to their question by asking, Is this the type of fast that I have asked for? There seems to have been an apparent misunderstanding between Israel's practice in fasting and what God requires from those who fast. "Their fasting did 
not please God, their fast was to gain divine approval. It was more important to God that they abstain from evil rather than abstain from food." It does not seem that the passage condemns fasting; rather, it seems that God could not accept fasting while iniquity was practiced.

\section{THE FAST THAT GOD REQUIRES}

God describes some important practices which should accompany true fasting. True fasting, like true religion, should loose the burdens from those who are oppressed. There are three categories of individuals that God shows great concern for: widows, orphans, and resident aliens. God expects that true fasting will lead His people to show concern for the widows, orphans, and resident aliens. The Bible is not only concerned with liberation from sin, it is also concerned about liberation from injustice.

\section{PRACTICAL RELIGION}

The passage under consideration is not implying that God is not concerned about religious rituals. The significant point that the passage makes is that religious rituals should not exclude practical Godliness such as, recognizing the need of those who are hungry and giving bread to the needy, bringing the poor to your house so that their needs can be met, and providing clothing for those who are naked. 
At the Embankment there are individuals who are hungry, there are those who are in need of warm clothing. How many of us are prepared to follow God's word by showing concern for the needy? How many of us would be prepared to open our homes to the homeless? Should we explore the possibility of opening the church during the week as a shelter for the homeless?

\section{BLESSINGS WILL COME}

The people were wondering why their fast was neglected by God. They may have been wondering why there was no spiritual renewal after their fasting. The context of the passage suggests that when fasting was accompanied by practical religion, God would add significant blessing to the people. Commenting on this, the passage says:

Then shall thy light break forth as the morning, and thine health shall spring forth speedily: and thy righteousness shall go before thee; the glory of the Lord shall be thy reward. Then shall thou call, and the Lord shall answer; thou shall cry, and he shall say, Here I am: If thou take away from the midst of thee the yoke, the putting forth of the finger, and speaking vanity, and if thou draw out thy soul to the hungry, and satisfy the afflicted soul; then shall thy light rise in obscurity and thy darkness be as the noon day.

\section{CONCLUSION}

God expects that religious rituals should be accompanied by practical religion. We should be concerned about those who are hungry, naked, and homeless. God has 
promised that when we are for those who are in need, He will hear our prayers and bless us.

\section{PURE RELIGION}

Pure religion and undefiled before God and the Father is this, to visit the fatherless and widows in their affliction, and to keep himself unspotted from the world (James 1:27).

In this text we see an example of James' method of teaching in which he makes a point by creating a contrast. For example, faith vs. works. In verse 26 he describes "Vain Religion." "If any man among you seem to be religious, and bridleth not his tongue, but deceiveth his own heart, this man's religion is vain." In verse 27 he describes pure religion. There are three elements which are consistent with pure religion: 1) to be undefiled before God, 2) to visit the fatherless and widows in their affliction, 3) to keep oneself unspotted from the world. In keeping with the theme of this series, we will look at two elements in the text, practical religion and moral purity.

\section{Practical Reliqion}

The positive evidence of practical religion consists of caring for orphans and widows. In the old Testament there are examples where God explicitly commands that orphans and widows should not be oppressed and that their needs should be met. For example, Ex 22:22, "Ye shall not afflict any widow, or fatherless child." Deut 10:18, "He doth execute the judgment of the fatherless and the widow 
and loveth the stranger, in giving him food and raiment." Here God is the one who takes care and protects the orphans and widows.

If we examine the significance of "visit," we will discover that to visit the orphans and widows is more than a casual visit. The real significance of "visit" is to take care, to look after the physical needs of the widows and orphans. The text invites those who practice pure religion to share in the pain of the widows and orphans.

\section{Moral Purity}

The second major division of the text suggests that practical religious action is not enough. Rather, practical religious actions should be accompanied by moral purity. "We should keep ourselves unspotted from the world." We should maintain the balance between the practical religion and moral purity.

\section{CONCLUSION}

God is still calling on us to care for those who are in need in the community and those outside the community. There are many orphans and widows who need our help. Let us keep the balance between practical Godliness and moral purity. 
APPENDIX C

GUIDELINES FOR DISCUSSION ON ELLEN WHITE'S

TEACHINGS ON THE CHURCH'S RESPONSIBILITY

TO THE POOR 
Outline 1

1. What instruction did God give about lending money to the poor? (P.K. 647)

2. What can we learn about the poor from Zacchaeus' response to Jesus' call? (D.A. 55)

3. What instruction does Ellen White give to the church about caring for its poor? (6T 270-71; M.H. 186)

4. How should employers deal with their poor employees? (P.P. 532) 
131

5. What was a significant part of worship in ancient Israel? (P.K. 662)

6. Text for meditation: Job $30: 25$ 
Outline 2

1. What promise has been made to those who help the poor? (G.W. 514)

2. How does Ellen White describe "The work that God has left us"? (P.K. 198)

3. What is an effective way of helping the poor? (M.H. 194)

4. Should we make distinction between the rich and the poor? (D.A. 403) 
5. What it God's intention that some should have plenty while others should beg for food? (C.O.L. 370-71)

6. Text for meditation: Prov 29:7 
outline 3

1. What is the "work to be done by our churches of which many have little idea, a work almost untouched"? (W.M. 189)

2. How do you respond to the following?

"There are today beside us many who are hungry, naked, and homeless. A neglect to impart of our means to these needy, suffering ones places upon us a burden of guilt which we shall one day fear to meet . . . all selfish indulgences is an offense in God's sight" (C.O.L.)

3. Should the poor be excluded from sacrificial giving? (3T 398)

4. What should be done with wealth as we come to the end of time? (C.O.L. 170) 


\section{5}

5. Should there be a balance between preaching the word and ministry to the needy? (A.A. 878-90)

6. Text for meditation: James $1: 27$ 
Outline 4

1. Should ministry to the poor and needy be restricted to those who are in the church? (W.N. 217-19)

2. What two responsibilities were placed on Israel after they delivered from Egypt? (P.P. 737)

3. Does the Lord permit misfortune to come to some people? (T.M. 287-88)

4. How should the rich deal with the worthy poor? (1T 481) 
5. Give examples of what constitutes pure religion (3T 516)

6. Text for meditation: Exodus 22:22-24 
BIBLIOGRAPHY 


\section{BIBLIOGRAPHY}

Abesamis, Carlos H. "Some Paradigms in Re-reading the Bible in a Third-World Setting." Mission Studies 7 (1990), 21-24.

Alana, Olu E. "Reconsidering the Poor by Gospel Norms." AFER 32 (1990): 193-200.

Alinsky, Saul D. Rules for Radicals. New York: Random, 1971.

Allard, Amanda. "Briefing on the Extent and Causes of Homelessness." The Children's Society, June 1997, 1.

Allen, Roland. Missionary Methods: St. Paul's or Ours. Grand Rapids, MI: Eerdmans, 1962.

Anderson, Elijah. Street Wise: Race, Class and Change in an Urban Community. Chicago: University of Chicago Press, 1990.

Bailey, Ron. Homelessness: What Can We Do? Oxford: Jon Carpenter, 1994.

- The Homeless and the Empty House. Harmonsworth, England: Penguin, 1977.

Bakke, Ray. The Urban Christian. Downers Grove, IL: InterVarsity, 1983.

- A Theology As Big As the City. Downers Grove, IL: InterVarsity, 1997.

Bennet, Willis G. Effective Urban Church Ministry. Nashville: Abingdon, 1988.

Bird, John. "Let's Do Business for the Underclass." Guardian, November 29, 1997, 1-2.

Boerma, Conrad. The Poor Side of Europe. Geneva: wCC Publications, 1989.

Boff, Leonardo, and Clodovis Boff. Introducing Liberation Theology. New York: Orbis, 1987. 
Booth, Charles. On the City: Physical Pattern and social Structure. Chicago: University of Chicago Press, 1967.

Brown, Colin. Dictionary of New Testament Theology. 1975. S.v. "Brother."

Brown, Raymond. The Message of Deuteronomy. Lester, England: InterVarsity, 1992 .

Bruce, F. F. The Book of Acts. New International Commentary. Grand Rapids: Eerdmans, 1988.

Cairns, Ian. Deuteronomy: Word and Presence. Grand Rapids: Eerdmans, 1992.

Christensen, Michael J. City streets, City People. Nashville: Abingdon, 1988.

Claerbaut, David. Urban Ministry. Grand Rapids: Zondervan, 1983 .

Coates, Robert C. A street is Not a Home. Buffalo, NY: Promoter, 1990.

Coggins, Richard J. "The old Testament and the Poor." Expository Times 99 (1987): 11-14.

Comblin, Jose. Cry of the Oppressed, Cry of Jesus. New York: Orbis, 1988.

Conn, Harvie. The American City and the Evangelical church: A Historical Overview. Grand Rapids: Baker, 1994.

Croatto, Severino. Exodus: A Hermeneutics of Freedom. New York: Orbis, 1981.

Cross, Robert D., ed. The Church and the city: 1865-1910. Indianapolis: Bobbs Merrill, 1967.

Davies, Margaret. Matthew. Shefield: JSOT, 1993.

Dawson, John. Taking our Cities for God: How to Break Spiritual Strongholds. Lake Mary, FL: Creation, 1998.

Dickinson, Raymond. "The Helpers." The Regent Hall Soup Run, 1997, 6-7.

Downing-orr, Kristina. Alienation and Social Support.

Hants: Gower, 1996.

Driggers, Carlisle B., compiler. Models of Metropolitan Ministry. Nashville: Broadman, 1979 . 
Dudley, Carl s. Basic steps Toward Community Ministry. New York: Alban Institute, 1993.

Dupertuis, Atilio Rene. Liberation Theology: Use of the Exodus, A Soteriological Model. Berrien Springs, MI: Andrews University Press, 1982.

Editorial. "Homeless Move Along." The Economist, February 6,1993 .

Elliott, Larry. "Britain's Poor Are Worse off Than Ever." The Guardian, September 9, 1998, 1-3.

Ellison, Craig, ed. The Urban Mission. Grand Rapids: Eerdmans, 1974 .

Elmer, Duane H., and Lois McKinney, eds. With an Eye on the Future: Development and Mission in the 21st Century. Monrovia: MARK, 1984 .

Elwell, Walter A. Baker Encyclopedia of the Bible. Grand Rapids: Baker, 1995.

Encyclopedia Britannica, 1971 ed. S.v. "Welfare State."

Fackre, Gabriel. Second Fronts in Metropolitan Mission. Grand Rapids: Eerdmans, 1967.

Fichter, Joseph H. Social Relations in the Urban Parish. Chicago: University of Chicago Press, 1968.

Fielding, Nick. "Is There a Doctor in the House?" New statesman and Society 9 (September 1988), 31 .

Fisher, Kevin, ed. Homeless Healthcare and Welfare Provision. London: John Collins, 1993.

Freedman, David Noel. "Poor." The Anchor Bible Dictionary. New York: Doubleday, 1992.

George, Vic, and Irving Howards. Poverty Amidst Affluence. Aldershot: Edward Elgar, 1991.

Gordon, Wayne L. Real Hope in Chicago. Grand Rapids: Zondervan, 1995.

Gray, Sherman w. The Least of These My Brothers: Matthew 25:31-46, A History of Interpretation. Atlanta: Society of Biblical Literature, 1986.

Green, Joel B. The Theology of the Gospel of Luke. Cambridge: Cambridge University Press, 1995. 
Greenway, Roger S., ed. Discipling the City: A Comprehensive Approach to Urban Mission. Grand Rapids: Baker, 1992 .

Grigg, Viv. Cry of the Urban Poor. Monrovia, CA: MARC, 1992.

- Companion to the Poor. Monrovia, CA: MARC, 1990.

Hagan, Andrew D. "Down and out in London." World Press Review, March 1994, 47.

Haines, Andrew. "Working Together to Reduce Poverty's Damage." British Medical Journal, February 22, 1997, 529-530.

Hamilton, Jeffries M. "Ha'ares in the Shemitta Law." Vetus Testamentus 42 (1992): 214-222. - Social Justice and Deuteronomy: The Case of Deuteronomy 15. Atlanta: Scholars, 1992.

Harvey, Anthony, ed. Theology in the City. London: SPCK, 1989.

Hessel, Dieter T. Social Ministry. Louisville: John Knox, 1992 .

Hetherington, Peter. "Blair Pledges Program to Bridge the Gap Between Rich and Poor." The Guardian, September $16,1998,1-2$.

Hobbs, T. R. "Reflection on the Poor and the old Testament." Expository Times 100 (1989): 291-294.

Holland, Joe, and Peter Henriot. Social Analysis: Linking Faith and Justice. New York: Orbis, 1986.

Holloway Seventh-day Adventist Church Minutes, December 4, 1984 .

"Homeless in England." Shelter, September 1995, 2.

"Homeless, Poverty, and Health." Crisis 17 (July 1998): 1.

Hopkins, Nick. "Homeless Crisis Gets Street Tsar." The Guardian, July 6, 1998, 1.

Houston, Tom. "Good News for the Poor." Transformation 7 (1990): 3-8. 
Hoyt, Thomas. The Poor in Luke-Acts. Duram, England: n.p., 1994.

James, Meikle. "Homeless: Deadly Serious Having No Home Is Not Just Distressing--It Can Be Fatal." Guardian, December 10, 1997.

Johnsson, william G. "Jesus Friend of the Poor." Adventist Review, May 6, 1993, 3 .

Juel, Donald. Luke-Acts. London: SCM, 1983.

Jute, Robert. Poverty and Deviance in Early Modern Europe. Cambridge: Cambridge University Press, 1994 .

"Luke." Seventh-day Adventist Bible Commentary. Edited by Francis D. Nichol. Washington, DC: Review and Herald, 1953-57.

MacArthur, John. Matthew 24-28. Chicago: Moody, 1989.

Mann, Thomas $w$. Deuteronomy. Louisville: Westminster, 1992.

"Matthew." Seventh-day Adventist Bible Commentary. Edited by Francis D. Nichol. Washington, DC: Review and Herald, 1980.

Matthew, stanley G. The Night Pastor. New York: Hawthorne, 1967.

Maynard-Reid, Pedrito U. Poverty and Wealth in James. Maryknoll, NY: Orbis, 1987.

Mays, D. H. Deuteronomy. The New Century Bible Commentary. Grand Rapids: Eerdmans, 1991.

Mcclung, Floyd. Seeing the city with the Eyes of God. Tarrytown, NY: Chosen, 1991.

McDonald, Trevor, and Michael Lawrence, eds. "Cold Kills!" LBC's Public Affairs Forum, 1994, 8.

Moore, Jeanne, David Carter, et al. The Faces of Homelessness in London. Aldershot: Gower, 1995.

Moore, Richard E., and Duane L. Day. Urban Church Breakthrough. New York: Harper \& Row, 1966.

Mott, Stephen Charles. "Because Jesus Was Homeless For Us A Biblical study and our Responsibility to the Poor." Christian Social Action 2 (1998): 4-15. 
Murray, stuart. City Vision: A Biblical View. London: Daybreak, 1990 .

National Council of YMCA. "If You Are Homeless." YMCA, November $1997,3$.

The New Jerome Biblical Commentary. Edited by Raymond $E$. Brown and Joseph A. Fitzmyer. London: Prentice, 1990.

Niebuhr, Richard H. Christ and Culture. New York: Harper \& Row, 1951.

Nolland, John. Luke. Word Bible Commentary. Dallas: Word Books, 1982 .

O'Hagan, Andrew. "Down and Out in London." World Press Review, March 1994, 47.

Oldman, Joseph, ed. "Homelessness--What's the Problem?" shelter (1994): 7 .

Oppenheim, Carey. "Poverty in London: An Overview." Child Poverty Action, December 1994,6 .

Pannell, Williams. Evangelism From the Bottom Up. Grand Rapids: Zondervan, 1992.

Pilgrim, Walter E. Good News to the Poor: Wealth and Poverty in Luke-Acts. Minneapolis: Augsburg, 1991.

"Place to Call My Own." Crisis-Shelter, December 1995, 22.

Plastars, James. The God of Exodus. Milwaukee, WI: Burce, 1966.

Plummer, Alfred. The Book of Luke. International Critical Commentary. Edinburgh: T. \& T. Clark, 1995.

Pritchard, James, ed. Ancient Near Eastern Texts.

Princeton, NJ: Princeton University Press, 1950.

Roland, Allen. Missionary Methods: St. Paul's or Ours? Grand Rapids: Eerdmans, 1962.

Ryan, William. Blaming the Victim. New York: Pantheon, 1971.

Salvation Army Social Services. "Mission statement of the Salvation Army." Salvation Army Information Pack on Homelessness, 1997,2 . 
- "Salvation Army Facts." The Salvation Army Information Pack on Homelessness, 1997, 3 .

Siqueira, Marcius C. "Ellen White and the Oppressed Poor." Adventist Review, May 15, 1980, 9-11.

strong, James. The New Strong's Exhaustive Concordance of the Bible. Nashville: Thomas Nelson, 1984 .

Sugirtharaja, R. A. "For You Always Have the Poor With You: An Example of Hermeneutical Suspicion." Asian Journal of Theology 4 (1990): 102-107.

Tamez, Elsa. "Good News for the Poor." Evangelical Review of Theology 11 (1987): 246-247.

Temple, william. Christianity and Social order. London: Shepheard-Walwalwyn, 1987.

Van Engen, Charles, and Jude Tiersma, eds. God so Loved the city. Monrovia, CA: MARC, 1994.

Von Rad, Gerhard. Deuteronomy: A Commentary. London: SMC, 1988 .

Wagner, C. Peter. Frontiers in Missionary Strategy. Chicago: Moody, 1971.

Wapple, Patricia A. "People sleeping Rough." Sleeping Rough, February 1997, 1.

Webster's Third New International Dictionary. 1961, s.v. "strategy."

Weir, Emmett J. "The Poor Are Powerless: A Response to R. J. Coggins." Expository Times 100 (1988): 13-15.

White, Ellen G. "The Beatitudes." Signs of the Times, May $9,1892,487$.

- "Blessed Is He That Considereth the Poor." Signs of the Times, June $20,1892,495$.

- "The Call of Isaiah." Advent Review and Sabbath Herald, March 4, 1915, 3.

- "The Coming Thanksgiving." Second Advent Review and Sabbath Herald, November 18,1884 .

- The Desire of Ages. Mountain View, CA: Pacific Press, 1940 . 
- "First-Day offerings and the Foreign Missionary Work." Advent Review and Sabbath Herald, October 6, 1891,609 .

- The Ministry of Healing. Mountain View, CA: Pacific Press, 1905.

- "Our Duty to the Poor." Second Advent Review and Sabbath Herald, November 19, $1861,198$.

- Patriarchs and Prophets. Mountain View, CA: Pacific Press, 1890.

- Prophets and Kings. Mountain View, CA: Pacific Press, 1917.

- The Southern Work. Washington, DC: Review and Herald, 1899. 22, 1880,6 .

- Testimonies for the church. 9 vols. Boise, ID: Pacific Press, 1985.

- Welfare Ministry. Washington, DC: Review and Herald, 1952 . 
VITA

Name: Carl Thorpe

Date \& Place of Birth: October 24, 1945

Limon, Costa Rica

\section{EDUCATION}

Bachelor of Theology, 1974

Master of Arts, 1985

Master of Divinity (Equivalency), 1996

Doctor of Ministry, 1999

PROFESSIONAL EXPERIENCE

Pastor, West Jamaica Conference, 1974-1980

Pastor, East Jamaica Conference, 1981-1986

Pastor, South England Conference, 1986-1995

Assistant Pastor, Trinity Temple, Kalamazoo, MI, 1996- 